\title{
Smart Sustainable Cities of the New Millennium: Towards Design for Nature
}

\author{
Chiara Catalano $^{1}$ (D) $\cdot$ Mihaela Meslec $^{1}$ - Jules Boileau ${ }^{2,3} \cdot$ Riccardo Guarino $^{4}$. \\ Isabella Aurich ${ }^{1}$ - Nathalie Baumann ${ }^{1}$. Frédéric Chartier ${ }^{5}$. Pascale Dalix ${ }^{5}$. \\ Sophie Deramond ${ }^{5}$. Patrick Laube ${ }^{1}$ • Angela Ka Ki Lee ${ }^{5}$. Pascal Ochsner ${ }^{1}$ • \\ Marine Pasturel $^{2}$ - Marie Soret ${ }^{2,6}$. Sylvain Moulherat ${ }^{2,7}$
}

Received: 4 February 2021 / Accepted: 22 July 2021 / Published online: 25 August 2021

(C) The Author(s) 2021

\begin{abstract}
Urban environments consist of a mosaic of natural fragments, planned and unintentional habitats hosting both introduced and spontaneous species. The latter group exploits abandoned and degraded urban niches which, in the case of plants, form what is called the third landscape. In the Anthropocene, cities, open spaces and buildings must be planned and designed considering not only human needs but also those of other living organisms. The scientific approach of habitat sharing is defined as reconciliation ecology, whilst the action of implementing the ecosystem services and functioning of such anthropogenic habitats is called Urban Rehabilitation. However, urban development still represents the main cause of biodiversity loss worldwide. Yet, the approach of planners and landscape architects highly diverges from that of ecologists and scientists on how to perceive, define and design urban green and blue infrastructure. For instance, designers focus on the positive impact that nature (generally associated with indoor and outdoor greeneries) has on human well-being, often neglecting ecosystems' health. Instead, considering the negative impact of any form of development and to achieve the no net loss Aichi's objectives, conservationists apply mitigation hierarchy policies to avoid or reduce the impact and to offset biodiversity. The rationale of this review paper is to set the fundamentals for a multidisciplinary design framework tackling the issue of biodiversity loss in the urban environment by design for nature. The method focuses on the building/ city/landscape scales and is enabled by emerging digital technologies, i.e., geographic information systems, building information modelling, ecological simulation and computational design.
\end{abstract}

Keywords Urban ecology · Biodiversity · Holistic design · Design with Nature · Nature-based solution $\cdot$ GeoBIM $\cdot$ DeMo

Chiara Catalano

cata@zhaw.ch

Extended author information available on the last page of the article 


\section{Introduction}

The urban sprawl linked to population growth and other human activities, such as the production and transportation of goods, are the main causes of habitat fragmentation and biodiversity loss [1-3]. The conflict between people and nature in urban areas (e.g., allergies, anxiety and unawareness) limits the chance of wild species survival in the built environment, also because land price discourages investments towards nature conservation in favour of more lucrative infrastructure (e.g., housing, construction of shopping centres and other places for entertainment). Moreover, our cities are often characterised by the unequal access of the population to green spaces, the distance of semi-natural areas from city centres and the scarcity and poor quality of suburban and peripherical recreational areas, often polluted, degraded or neglected [4, 5]. The above-mentioned issues are some of the reasons that brought to define benchmarks like the sustainable development goals (SDGs) [6-8] and the Aichi biodiversity targets [9], but also to set up monitoring programmes strongly addressed to policymakers [10]. It is clear that we must take responsibility as human beings and act to protect our life-supporting system: planet earth [11]. As the ecologist Odum pointed out, ecology can act as trait d'union between natural and social sciences [12]. The deterministic and sometimes dogmatic understanding of science drove to the revolutionary thinking that motivated and inspired the first ecological designers and planners [13].

\section{Design with Nature}

In the popular and inspiring book Design with Nature, McHarg [14] explained the ecological planning method he developed with his multidisciplinary team. This method aimed at identifying the most suitable land for human activities (urbanisation and hard infrastructure) to reduce or exclude their impact on the most sensitive areas, i.e. vulnerable and rare ecosystems. The reasoning behind the ecological planning method relied on what we would call today ecosystem services, considering that McHarg affirmed that nature performs work for men (e.g., water purification, atmospheric pollution dispersal, drought and erosion control and topsoil accumulation) and it does it at the natural stand at its best. This concept was known as physiographic determinism where development should respond to the operation of natural processes [14].

The ecological planning method was one of the first to integrate social and economic spatial data (e.g., urbanisation, agricultural, historical and recreational) with geographic and ecological ones (e.g., topography, erosion risk, plant ecology and wildlife) into urban planning and design. In this method, the first step was to collect the major scientific ecological data (e.g., concerning climate, human history, geology, physiography, hydrology, soil properties, plant ecology, habitats and land use), then to select the most relevant data for each macro-category (e.g., within climate the air pollution or within physiography the slope) and finally to interpret them in terms of values and tolerance/intolerance for certain type of development/land use. General targeted uses were future recreation, conservation, residential and industrial/ commercial development drown on maps of hierarchical land fitness or optimum: these thematic gradient maps were produced by representing each value adopting a greyscale, from most to least or vice versa, then by superimposing all of them in colour. This approach demonstrated that a certain region was suitable for multiple compatible uses showing the degree of inter-compatibility. 
McHarg's legacy is visible in both humanistic and scientific fields of research because, on the one hand, this approach aimed to reconcile men with nature and to increase human wellbeing, whilst on the other, it showed the possibility to implement a systematic and rigorous approach also in a creative field like landscape and urban planning [13]. In fact, the proposed method was rational and reproducible thanks to the traceability of the data sources and the deterministic choices. For example, the novelty of working with superimposed layers is used to produce landscape suitability maps using modern geographic information systems (GIS) technologies for geodesign purposes [15, 16], environmental analysis [17-19] and past and recent modelling [20-23].

\section{Mitigation Hierarchy}

Despite the intent McHarg had to pervade landscape architecture with scientific ecological knowledge, in the end he aimed at getting the maximum social benefit at the least social cost. Therefore, his method responded to the current practice, where environmental protection was still seen as a development restrain, conditioning its expansions or its orientations [24, 25]. This mechanism persists up to now wherever natural reserves are often located in remote and unproductive areas which are not necessarily representative, in terms of biodiversity, of a certain region [26].

Another tool emerged in the late 1990's, developed to serve the ambition of limiting the impact on ecosystems: the mitigation hierarchy. This hierarchy, applied indeed as a sequence, states that impact of human activities should be assessed, avoided, reduced and finally, offset if needed [27]. Yet, too often, the first step, i.e., the avoidance is neglected [28-30] to privilege the overuse of biodiversity offsetting $[31,32,33]$ : a compromise not efficient enough to stop biodiversity erosion [34]. Several examples show that biodiversity offsetting does not fully compensate the impacts of urban development on past and ongoing losses of our lifesupporting system [35-38].

Another weakness of the mitigation hierarchy is the emphasis set on the local scale. Instead, the biodiversity functioning must be considered first at the landscape scale and the mitigation hierarchy sequence should be integrated within urban planning. This, to address the impact of urban development and to serve as a major constrain and orientation guide for any development [39-41]. Thus, the socio-economic development shall be considered at the very last stage of the process of landscape planning, once the ecological network and the conservation priorities are understood and set [19]. In their paper, Calvet et al. [19] proposed to consider as the first step of urban planning a comprehensive and robust understanding of the ecological functioning at the city scale (habitat description and conservation quality assessment, species occurrence and rarity, functional connectivity evaluation, etc.).

In this respect, the identification of the sites to spare from the development on the base of their role in the ecological functioning and resilience, as well of the sites where urbanisation would have less impact, could be of great interest for conservation planning. Besides, such functional work permits to identify in the built part of the landscape the most interesting places to foster biodiversity functionalities (habitat restoration or creation, corridor improvement, etc.). This approach would allow for instance the urban development to implement a natural grid, functional enough to keep species resilience within the territory under development [39, 42]. Maximising both the sustainability of the built landscape and the benefits to local ecosystem dynamics, development projects must reflect a larger context/scale to obtain a systemic biodiversity conservation planning [26, 39, 41] yet linked with urban development targets $[19,43,44]$. 


\section{The Potentiality of Digital Technologies to Foster Biodiversity by Design}

Standard tools might not be efficient enough to cope the entire complexity of biodiversity within a landscape [45], but they must be implemented to evaluate the costs of the conservation and the ecological functioning within a territory, in line with conservation targets set by landscape managers [46-48]. Once the conservation targets are clearly defined, the conservation strategy, namely, the mitigation hierarchy adopted in the urban development plan, can be properly implemented, with both optimal time and right spatial scale [19, 39, 49]. Following this framework, urbanisation is designed to contribute to biodiversity preservation and restoration as well as producing services for inhabitants. This shift fits perfectly with the mainstreaming of biodiversity conservation, recommended by the latest frameworks of mitigation and conservation hierarchy [50].

The technological and the digital innovations in real estate known as PropTech [51] would offer solutions not only to the common challenges among real estate stakeholders - such as cost overruns, lack of transparency and fragmentation of the real estate industry - but also to address critical sustainability challenges such as the integration of life cycle analysis (LCA) [52] or biodiversity features. Live environmental data are more and more freely available in form of building information modelling (BIM) data and geographic information system (GIS) datasets. This would facilitate the implementation of biodiversity components into the early phases of a project, but this option is not yet empowered [53]. Instead, BIM and latest developments in GIS have proved to be useful merely in typical design and construction use cases, generally categorised in the following eight groups [54]: time-saving, material-saving, cost-saving, improvement in health and safety, reduction in risk, improved asset utilisation and improvement in asset quality for the end-user. By overcoming interoperability issues, the integration of BIM models, embedding data and information linked with the virtual and even real buildings (digital twins) with GIS datasets (GeoBIM) [55] would offer more opportunities to integrate crucial sustainability issues such as biodiversity loss and habitat fragmentation.

\section{Aims of the Paper}

To reduce the growing impact of the building sector on biodiversity loss, some of the possible actions are the conservation of remnant ecosystems, the reduction of their fragmentation and their restoration across the built environment [56]. In other words, conservation must be integrated within urban planning and the built landscape matrix shall become less hostile for wild plant and animal species. To fulfil these aims, there is the need to integrate scientific ecological knowledge in the design and planning of built-up areas (landscape-urban-building scales) by implementing on the one hand multidisciplinary frameworks enabled by digital technologies, and on the other hand, adequate sustainability assessment procedures and standards.

In this work, we present a new multidisciplinary framework and holistic design approach to tackle the issue of biodiversity loss and habitat fragmentation across multiple scales (landscape, urban and building). The DeMo framework is developed within the international project Design and Modelling of Urban Ecosystems: A spatial-based approach to integrate habitats in constructed ecosystems (hereafter: DeMo). The ambition of this framework is to enable ecologists and designers to cooperate from the early stage of a project to integrating habitats and facilitate the species colonisation of, and the movement through, built areas. Here, digital technologies, such as GIS, BIM, and ecological modelling shall enable and activate the 
necessary synergies among different disciplines through iterative and consultative processes. Besides, it is crucial that the framework we present here is well set within the SDGs and Aichi's targets; thus, it is necessary to identify the relationships among the two agendas and to find out how to structure a framework fitting both of the agendas from the beginning.

Our hypothesis is that some of the obstacles preventing the implementation of truly multidisciplinary environments are the disciplines territoriality and the framework-specific degree of novelty, but how to overcome these barriers? How to activate the synergies by joining approaches and techniques generally used separately? Another critical issue we identified is that in the era of open data, the myriad of spatial and ecological information might hinder the collaborative framework if not thoroughly screened, evaluated and properly selected. For example, are the data informative enough? Which environmental parameters (e.g., climate, topography and hydrology) and biotic data (e.g., habitats and species distribution) should be considered when designing through different scales (landscape-urban-building)? At which level of detail and spatial resolution? In terms of novelty, how to make meaningful use of ecological data for a multifunctional and across-scale design and how to integrate ecological information from the very beginning of a project? Finally, how to translate ecological data into urban and architectonic forms?

To start answering these questions this paper presents an expert-based literature review whose results constitute the theoretical background of the new designing approach we intend to develop during the ongoing DeMo Project. This review shall highlight how each discipline could contribute to the paradigmatic shift from design with nature to design for nature in terms of mainstreamed practices, innovative computational tools, and semi-automatic processes. Also, we believe that at the building scale, the performance-driven design is a standard common praxis probably because it got boosted by the introduction of green building standards, e.g., LEED, BREEAM and DGMB [57]. These standards define quantifiable performance requirements, but do they give enough weight to issues like habitat loss? To which extent do they consider the ecological role that buildings might play in supporting urban biodiversity? With this paper, we aim at identifying the gaps of such assessments, believing that their thorough revision under the lens of biodiversity would boost biodiversity-oriented design.

In short, the steps and aims of this paper are the following ones:

(1) Develop an expert-based transdisciplinary literature review, constituting the theoretical underpinning for our vision of designing for nature

(2) Identify crucial shortcomings of green building standards and smart cities assessment in properly considering biodiversity aspects

(3) Propose a novel framework for designing for nature that is well set within the SDG and Aichi's biodiversity targets

\section{Procedure to Develop the Theoretical Underpinning}

\section{The Expert-Based Literature Review}

The first core contribution of this paper is an in-depth literature review over the fields of conservation biology, environmental and architectural design. The review aimed at identifying on the one hand innovative approaches to design for biodiversity, on the other hand, 
information and communications technology (ICT)-enabling processes suitable to be used in biodiversity-sensitive design according to the following procedure (Fig. 1):

1. The first step was to disentangle environmental design approaches through an expertbased review (not systematic). Special attention was set on (1) the scale of intervention, i.e. landscape, urban and building scales and (2) the possible synergy and transdisciplinary applications.

2. The second step was to highlight the computational tools and the ICT-enabled processes used in innovative design and conservation biology approaches.

\section{Smart Cities and Building Sustainable Assessments}

Applied research on smart cities and sustainable building assessments was screened to find out into which level of complexity these assessments take into consideration biodiversity measures. To this purpose, we reviewed the Japanese Comprehensive Assessment System for Built Environment Efficiency for Cities (CASBEE-City) and the German Sustainable Building Council (Deutsche Gesellschaft für Nachhaltiges Bauen) (DGNB) multicriteria.

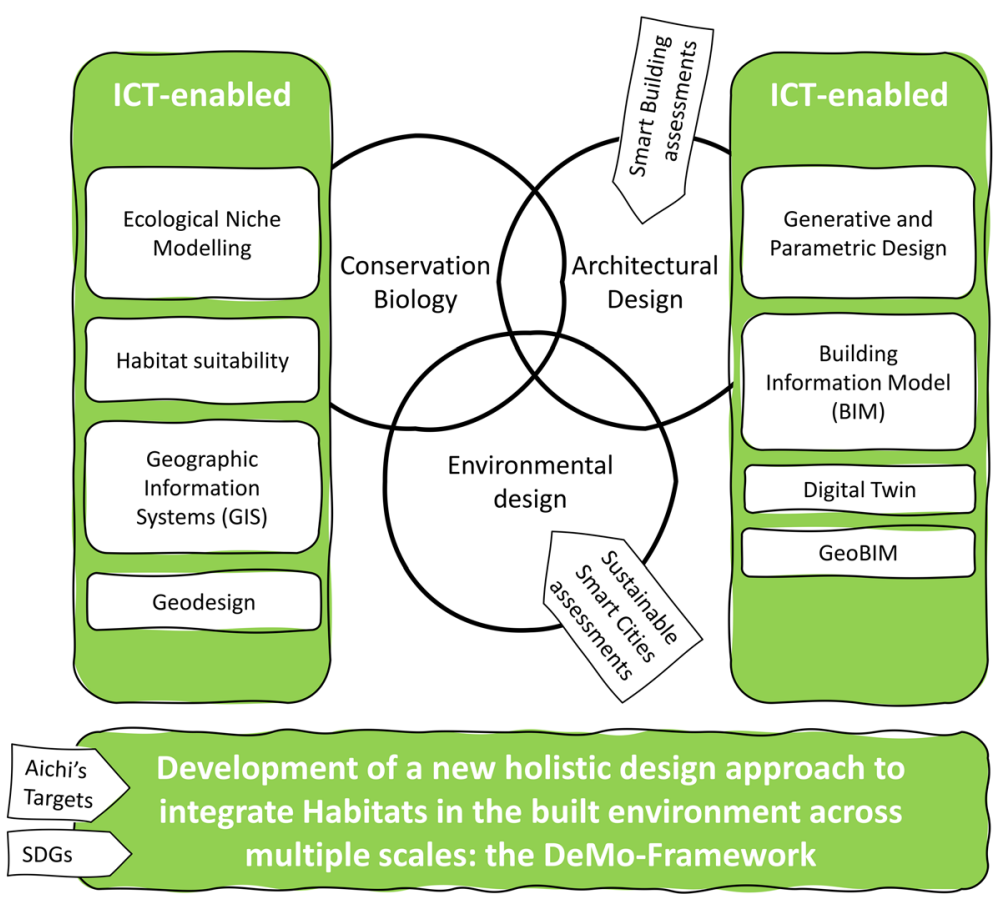

Fig. 1 Graphical description of the methodology used to develop the theoretical background of the holistic framework. The circles envelope the core disciplines under review; the arrows point the determinant standards, assessments and sustainability agendas out. The two embedding green vertical rectangles present ICT-enabled tools facilitating synergies and doomed to expand the possibilities of the core disciplines towards design for nature 


\section{Theoretical Background and Critical Literature Review}

\section{Highlighting the Synergies Across Scales and Design Disciplines}

\section{Eco-Positive Design}

Times are mature to mainstream the paradigmatic shift from environmental-sensitive to ecopositive design [58]: a positive development in which the core idea is to design for nature as well as for people. Tratalos et al. [59] showed that the ecosystem services (measured according to tree cover, green open areas, storm water run-off, temperature and carbon sequestration) decrease with the increasing of urban density and that it is possible to intervene on the type of development and housing to maximise ecological functions. For example, according to the eco-positive design approach, the built environment shall give back to nature more than what it takes/consumes [60]. Going beyond regenerative development [61], positive development is possible only if we learn to design integrated eco-services and to eco-retrofit our cities [58]. Thus, changing perspective, urban eco-services (vs. ecosystem services) [62] aim at regenerating local habitats in a logic of net-positive offsetting, namely, overcompensating the negative impact of the construction, going beyond the pre-settlement conditions [35]. In this sense, eco-retrofitting implies the integration at the whole urban scale (building, city and infrastructure) of small strategic improvements which solve urban problems while increasing both natural and social capital [63]: like in a symbiotic development-environment relationship, cities shall both preserve and enhance biodiversity. The action of repairing the ecosystem structure, functioning and services is generally called ecosystem rehabilitation, $[64,65]$ and by extension, we could refer to urban ecosystem rehabilitation when it is related to urban novel ecosystems [64]. These sorts of actions fall not only within ecological engineering but also within applied ecology [66].

\section{Biodiversity-Sensitive Cities}

Supporting and conserving biodiversity in urban environments is challenging [67, 68]; nevertheless, several works show promising opportunities to do so [69]. For example, Apfelbeck et al. [70] in the wildlife-inclusive design framework (Fig. 2a) suggest to select target species starting from both the regional species pool (georeferenced species data) and the local species potential determined by the existing habitat type around and within the development site (filter habitats). Furthermore, the authors suggest to analyse the site to address implementation strategies based on the animal-aided design (AAD) approach [72], finally, to consider the interaction human-animal traits to obtain the final species selection (before involving local stakeholders). The most important feature of the AAD is the species portrait, which contains the general traits of the species and their life cycle, thus providing designing aids based on species life stage and specific needs [72].

A complementary approach refers to habitat analogues $[73,74]$ used to inspire the plant species selection (see also the habitat template approach in the following paragraph) based on the similarity between both urban hybrids and novel ecosystems [75] — where some native species still thrive - and the natural analogues, namely, both urban natural remnants (or historical ecosystems sensu [76]) and natural areas, where these species live. This approach fits well within the concept of reconciliation ecology or win-win ecology [77], where people live and work [78]. It is possible to intervene on urban hybrid and novel ecosystems either by 


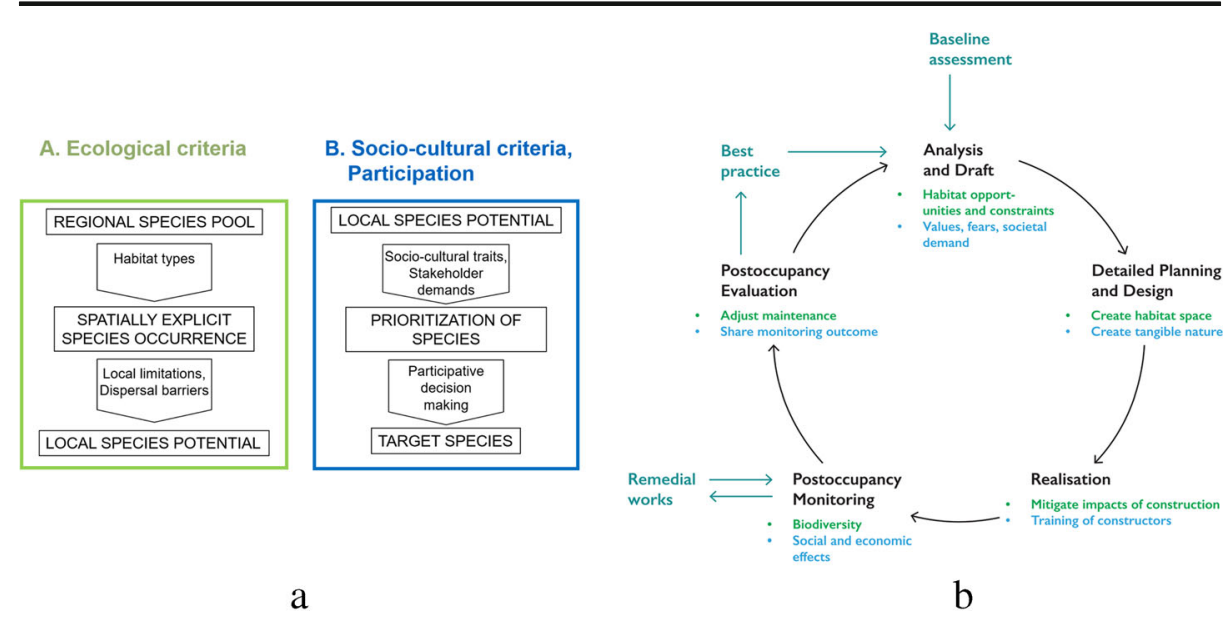

Fig. 2 a Ecological and socio-cultural criteria adopted in the wildlife-inclusive design framework (from [70]). b The planning cycle of the wildlife-inclusive urban design framework (from [71])

introducing propagules from natural analogues and/or altering them to support more native species (e.g., creation of brownfields) or just preserving ordinary biodiversity [79]. In any case, to design wildlife-inclusive [71] and biodiversity sensitive cities [80], conservation biologists will have to be involved in the whole life cycle of the project (Fig. 2b), from the beginning of the designing process to the management and monitoring [81]; and vice versa, designers shall be incorporated into applied ecology frameworks [66]. Thus, the exchange between designers and ecologists needs some work to align perspectives and approaches oras Parris et al. [82] argued-to turn on the lamps.

Interestingly, within the discipline of Urban Ecology, the ecology for the city approach evolved from the ecology in the city and the ecology of the city, with a paradigmatic shift towards the stewardship, thus involving not only scientists but also citizens, professional practitioners and decision makers [83]. For example, the meta-city term was introduced in 2007 by UN-HABITAT to identify large agglomeration of cities with more than 20 million inhabitants, polycentric and with diffuse governance [84]. McGrath and Pickett [85] intend the meta-city model as a conceptual framework to integrate ecology, architecture and urban design, incorporating digital sensing and communication technologies to achieve social sustainability and ecological resilience [86]. Cities evolve and, regardless from their dimension and type, the urban patchy system of systems is connected worldwide with fluxes of matter, energy, organisms and information (see the concept of metapopulation and metacommunities in ecology [87, 88]). The meta-city framework was adopted for the Baltimore Ecosystem Study over two decades reflecting the biological-physical-social nature of the Baltimore ecosystem [89].

The ecology of the meta-city is characterised by the urban meta-mosaic of landscape patches (both natural and artificial) and human infrastructure. To set up the tool of the metacity framework [90], recognition, history and evolutionary chances for every patch are also crucial to understand its dynamics. This framework of urban meta-mosaic can be applied in old central cities, suburbs, edge cities, exurbs and fringe, and it is constituted by three mosaic components in a feedback loop: process (e.g., biogeochemical fluxes, demographic change and information flux), choice (e.g., decisions made by organisms and individual people) and outcome (e.g., spatial patterns issuing from choices and processes). Finally, urban adaptation 
and resilience come into play [91]. Engineering resilience refers to the ability of the system to resist and come back to the level of equilibrium after disturbance; ecological resilience instead refers to the ability of the system to adjust to changing or unstable conditions (based on nonequilibrium theory). The adaptive cycle that derives from the latter approach is related to resilience, connectivity and accumulation of resources (capital): a system is prone to be less resilient if the dominating components are conservative ( $\mathrm{K}$ strategy) and connected; vice versa, if the dominating components can promptly and effectively respond (' $r$ ' strategy) and are less connected one another [91]. The adaptive cycle model is quite relevant in urban environments, which are evolving into complex systems changing land use at high speed, thus exacerbating inter-intraspecific competition. Thus, the transition towards sustainable cities can be done only by adopting holistic design approach, a circular economy model for resource management and implementing nature-based solutions [92, 93].

\section{Biodiversity-Sensitive Buildings}

The species which can thrive and withstand urban conditions (e.g., mechanical disturbance, non-native species competition, steep and sterile surfaces, urban heat island effect, and habitat fragmentation) shape what Clément [94] defined the third landscape but also unintentional landscapes [95] or informal green spaces (IGS) [96]. These species exploit ecological niches which were not created intentionally, so that they form communities that appear to the most as messy and untidy [97]. Nevertheless, the strategies adopted by the species populating unmanaged interstitial habitats can not only inspire designers to intentionally replicate such conditions in buildings $[98,99]$ but also help to define strategies for urban biodiversity conservation [75]. In the optic of reconciliation ecology (see the previous paragraph on the urban scale), green roofs and walls offer a great potential to support biodiversity [100] while providing several ecosystem services as multifunctional units [101].

Even if sustainable architecture is generally related to energy and resource consumption efficiency (paradigm which is mainstreamed in sustainability assessment tools, see the first section of this contribution), there are several schools and fields of applied research which can lead to net-positive buildings [60]. For example, when renovating or constructing a new lowor zero-carbon building or renovating one, the loss of biodiversity must be considered too, and ecologists must be addressed early enough, for instance, to allow architects to integrate suitable nesting and roosting habitats for building-reliant species like birds and bats [102].

According to the net-positive sesign approach [103], "Buildings must not only become eco-productive (i.e., eco-produce clean energy, water, soil, air, and food), but must reverse the impacts of previous development and expand indigenous ecosystems and ecosystem service in absolute terms". This is exemplary put in practice in some imaginative projects inspired by natural forms and functions (biomimicry) such as the eco-skyscrapers conceived by Ken Yeang [104] and the big floating selfsufficient structures of Vincent Callebaut [105]. In both these projects, the link between eco-design (e.g., LCA) and biomimicry is quite crucial. Nevertheless, the main question here arises: which kind of biodiversity is supported by such projects? How to shape the building envelope so to host target flora and fauna?

In the pioneering building by Chartier-Dalix architects for the Boulogne Billancourt Biodiversity School and Gymnasium constructed in 2014 in Paris [106, 107], the building was seen as a holistic system allowing to work with architecture and biodiversity 
simultaneously [108]. The collaboration between architects and ecologists enabled to integrate into the building not only extensive, semi-intensive and intensive green roofs but also to conceive a living habitat façade to host animals and plants by designing various gaps and voids meeting the requirements of targeted birds, arthropods and stress-tolerant plant species (Fig. 3).

The building was designed to fulfil the school activities, functions and requirements, but at the same time to host plant and animal species considered as part of the body of the building rather than as mere add-ons. This shift of perspective and this new manner of approaching the project turned the school into a life-size tool for experimentation: the structure is a living observatory in a dense urban environment apt to monitoring the reciprocal influence between plant and animal species and the building. This also implies a total and profound change of the way urbanisation is defined, maximising the ecological functionality within the landscape and the rationalisation of costs and efficiency to preserve it. To this respect, the selection of the target habitats and, therefore, of the species to favour on the building should be driven by the conservation targets at a higher planning scale, maximising the efficiency of buildings aimed at supporting biodiversity [43, 109].

One practical key/tool enabling architects to design life-hosting buildings proved to be a catalogue of ecological niches and species requirements [99, 102, 106, 110, 111] containing descriptions and sketches illustrating key biophysical aspects to host animals and plant assemblages (Fig. 4 and Table 1). For example, characteristic shapes (e.g., access and nesting dimension), suitable material properties (e.g., rough, smooth and metal, wood), likely position (e.g., minimum or maximum height from the ground or distance from the roof), proximity to certain structures providing different services (e.g., foraging, hiding and roosting), favourable aspect (e.g., north/south), sun exposure and temperature (e.g., light/shade). To this regard, attractive visualisation [112] of the urban section showing adaptation to biodiversity along streets, houses but also private gardens, proven to be useful to raise awareness and encourage people of willing to have more nature in their own backyard.

\section{City and Building Assessments}

SDGs and Aichi targets are starting to be integrated into the rich panorama of sustainability assessment systems, which are crucial to predict and evaluate the impact of human activities on ecological systems, and supporting decision making. However, smart and sustainable is not necessarily a synonymous of biodiversity-friendly. In fact, a proper evaluation of biotope quality or biodiversity status is often neglected or poorly considered in city assessments at both urban and building scales, as highlighted in the following paragraphs.
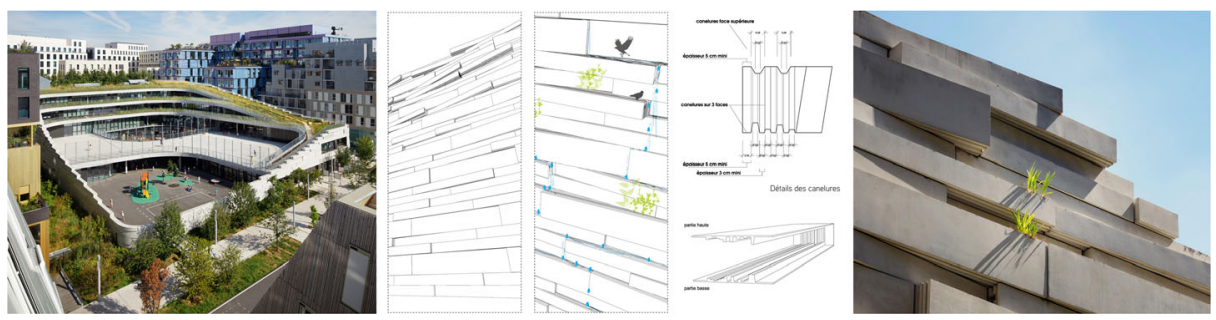

Fig. 3 Boulogne Billancourt Biodiversity School and Gymnasium constructed in 2014 in Paris by ChartierDalix architects. (photos and drawing credits: Chartier-Dalix architects) 


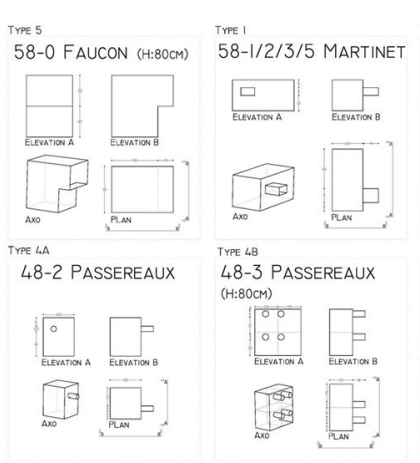

a
48-I PASSEREAuX

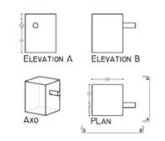

TYPE 6

48-4 58-4 38-0

HIRONDELLE

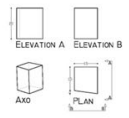

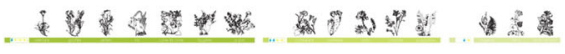

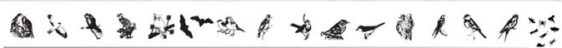

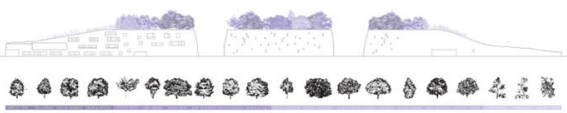

$\mathrm{b}$

Fig. 4 a Illustration of some bird species requirements (faucon: falcon; passereaux: passerines; hirondelle: swallow) and $\mathbf{b}$ distribution of the selected plant and animal species on the façades and the roof of the Boulogne Billancourt Biodiversity School and Gymnasium in Paris (drawing credit: ChartierDalix Architects)

\section{Sustainable Smart Cities}

Several definitions of smart city exist $[113,114]$, but there is a certain common agreement on the 6 dimensions characterising them: (1) smart economy (industry and competitiveness), (2) smart mobility (transport and information and communications technology (ICT)), (3) smart environment (natural resources), (4) smart people (social and human capital and education), (5) smart living (quality of life) and (6) smart governance (participation). Some uncertainty in terms of definition arises when dealing with sustainable city or urban sustainability, also

Table 1. Relationships between spontaneous plants and urban man-made habitats (translated and modified from [99])

\begin{tabular}{|c|c|c|c|c|c|c|}
\hline $\begin{array}{l}\text { Relationship between plant } \\
\text { location (PL) and water- } \\
\text { capturing surface (WcS) }\end{array}$ & Geometry & $\begin{array}{l}\text { The slope } \\
\text { of the } \\
\text { surface }\end{array}$ & Orientation & Topology & Materials & $\begin{array}{l}\text { Position of } \\
\text { the roof } \\
\text { gutter }\end{array}$ \\
\hline Distance between PL and WcS & $\begin{array}{l}\text { Flat } \\
\begin{array}{l}\text { Upper } \\
\text { horizontal } \\
\text { dihedral }\end{array} \\
\\
\begin{array}{l}\text { Lower } \\
\text { horizontal } \\
\text { dihedrals }\end{array} \\
\\
\text { Vertical } \\
\text { dihedral }\end{array}$ & $\begin{array}{l}\text { Horizontal } \\
\text { Tilted } \\
\text { Vertical } \\
\end{array}$ & Z [zenith] & Material porosity & $\begin{array}{l}\text { Steel } \\
\text { Aluminium } \\
\text { Concrete } \\
\text { Bitumen } \\
\text { Ceramic } \\
\text { Wood } \\
\text { Brick } \\
\text { Coat on concrete } \\
\text { Coat on stone } \\
\text { Cast iron } \\
\text { Granite } \\
\text { Sandstone } \\
\text { Marble } \\
\text { Mortar } \\
\text { Limestone } \\
\text { Siliceous stone } \\
\text { Plastic } \\
\text { Stabilised } \\
\text { Soil } \\
\text { Zinc }\end{array}$ & $\begin{array}{l}\text { Pavement- edge } \\
\text { Pavement- } \\
\text { surface } \\
\text { Column- } \\
\text { basement } \\
\text { Grating } \\
\text { Fencing- wall } \\
\text { Wall-base } \\
\text { Staircase } \\
\text { Dry-stone-wall } \\
\text { Gutter } \\
\text { Wall } \\
\text { Headwall }\end{array}$ \\
\hline
\end{tabular}


because these two terms sound like an oxymoron to most people $[115,116]$. What is of common understanding is that a sustainable city must fulfil the balance between social equity, economic development and environmental protection [117, 118]. Even if both smartness and sustainability concepts seem to be similar, smart assessments lack of environmental indicators and generally prioritise ICT efficiency on their environmental impact, while the sustainable assessments prioritise environmental and social sustainability indicators at the expense of the economic ones [117].

To overcome the discrepancy between smart and sustainable approaches, the term sustainable smart city emerged in the last decade $[116,119,120]$, qualifying a city that [120]: "[...] meets the needs of its present inhabitants, without compromising the ability for other people or future generations to meet their needs, and thus, does not exceed local or planetary environmental limitation, and where this is supported by ICT". The smart sustainable city embraces the challenge to adopt a holistic approach in line with SDGs but it is still at the early stage of conceptualisation and put into practice [121].

Each of the above-mentioned six dimensions of a smart city can be assessed (smart city ranking) using specific factors and indicators [113, 122, 123]. The indicators proposed by Lombardi et al. [124] are determined by linking the six dimensions of the smart cities to a modified triple helix model which is at the base of the process of knowledge creation and capitalisation: university, industry, government and civil society (a model of four helices). In this framework, within the smart environment figure several indices, which however did not target biodiversity conservation issues:

- the assessment of $\mathrm{CO}_{2}$ emissions strategies of the standards for buildings efficiency (university helix)

- energy and water consumption, green areas $\left(\mathrm{m}^{2}\right)$, containment of urban sprawl, air pollution, citizen participation and engagement and use of clean transport means (government and civil society helix)

- recycled waste and number of sustainability assessments (industry helix)

Although the indicators of environmental sustainability prioritise ecological issues, there is still a lack of qualitative measures as it happens in one of the most advanced sustainable assessment tools, i.e., the Japanese Comprehensive Assessment System for Built Environment Efficiency for Cities (CASBEE-City) $[125,126]$. Among CASBEE-City indicators, only one of them deals with nature conservation and is based on the ratio between the sum of green and water areas and the total surface included in the political boundary of the municipality (i.e., merely a quantitative measure). However, a recent update of CASBEE-City has been proposed to assess cities worldwide (pilot version). This is inspired by both the SDG goals (and indicator) and ISO37120: 2014 (Sustainable development of communities) [127-129]. As a result, the category tackling the environmental performance (Q1) got several candidate indicators more than in the actual edition. Among them, the ones relevant to nature conservation are the green areas (hectares) per 100,000 inhabitants, the annual number of trees planted per 100,000 inhabitants, the share of coastal and marine areas that are protected, the annual change in forest area and land under cultivation, the rate of forest surfaces managed according to sustainable silvicultural practices, the annual change in degraded or desertified arable land, red list index, the effective overlap of protected areas overlay to fulfil biodiversity conservation policies and the percentage change - in terms of number - of native species.

The pilot version of CASBEE-city seems to be the first case of partial integration of the City Biodiversity Index (CBI) also known as the Singapore Index on cities' biodiversity [130]. The CBI 
was endorsed by the convention of biological diversity in 2009 [131, 132] and is based on three pillars: (1) native biodiversity, 2) ecosystem services (e.g., cooling effect of the vegetation), and (3) governance and management of biodiversity (e.g. budget devoted for biodiversity conservation initiatives). Probably, one of the reasons why the CBI index was not adopted more extensively might be the difficulty to find adequate data (open access data availability) or the high effort to gather high-resolution spatial data. Nevertheless, some of the issues can be overcome by analysing land use datasets $[133,134]$ like the free available global land use datasets [135]. In detail, the CBI performs a quantitative assessment of the native biodiversity component by using the following 10 indicators: (1) proportion of natural areas in the city, (2) connectivity measures or ecological networks to counter fragmentation, (3) native biodiversity in the built-up area (only bird species), (4-8) net change in the number of native species ((4) vascular plants, (5) birds, (6) butterflies and $(7,8)$ any other taxonomic group), (9) proportion of protected natural areas and (10) proportion of invasive alien species. Even if the 23 indicators are quite robust, some recent studies proposed to implement the second indicator on the connectivity of natural areas by taking into account also the within-patch connectivity/barrier [136].

\section{Sustainable Buildings}

There are plenty of building sustainability assessments worldwide [125]. Going beyond the single-dimension assessment, based, for instance, on the energy consumption (i.e., cumulative energy demand, such as the zero-energy buildings) or environmental load (i.e., life cycle assessment (LCA)), the multidimensional assessment accounting for the total quality assessment enables to evaluate the different sustainability dimensions (i.e., economical, ecological and social).

In Europe, the German Sustainable Building Council (in German: Deutsche Gesellschaft für Nachhaltiges Bauen, DGNB) multicriteria for the building sector aims at measuring the quality of the three (environmental, social and economic) pillars of sustainability giving to them equal weight, but accounting also for technical processes and site quality, in this order of importance (Fig. 5) [137].

Moreover, each of these criteria was recently screened to determine its contribution to the SDGs [138]. As a result, since 2018, the biodiversity at the site figures within the six criteria related to environmental quality (Fig. 6). However, this criterion sums up to $1.2 \%$ of the total certification score, having the lowest relevance among the indicators contributing to the whole assessment. Among them, the biotope area quality is a function of the property-specific biodiversity index (calculated by a provided excel tool, (C) DGNB $\mathrm{GmbH}$ ) and is measured on the base of land cover (with and without vegetation), water infiltration, soil contiguity with the ground and presence of green walls and green roofs.

Further, the value for species diversity in the proximity of the site and on the building is obtained by evaluating the measures adopted to support the existing species (the status quo) and to encourage the colonisation of new ones through either direct introduction (e.g., planting new native plants) or designed features. The latter measure intends to make the outdoor area and the building more attractive for target species of birds, bats, butterflies, wild bees, wasps, amphibians and reptiles. The DGNB endorsed to this respect the AAD approach [71, 72].

Summarising, building and urban sustainability assessments seem to be more centred on the rational use of environmental resources than on biodiversity issues, allowing to design less unsustainable buildings [63] instead of net-positive buildings [139]. For instance, the highly detailed DGNB system adopts an extremely simplified biotope index, which does not include qualitative 


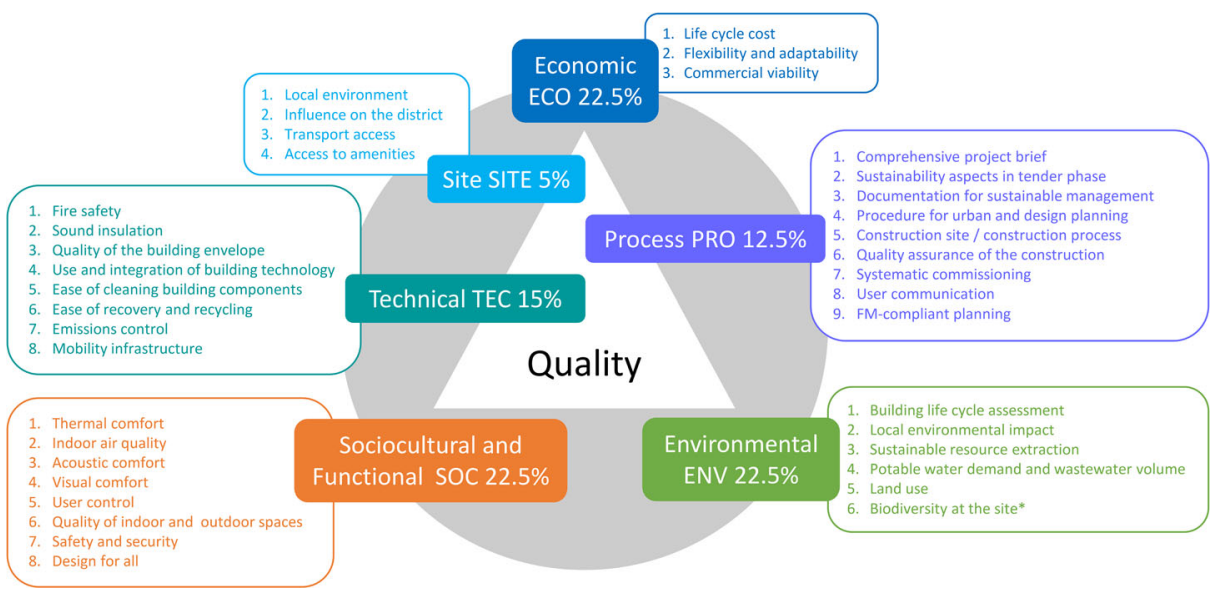

Fig. 5 DGNB criteria for new buildings [137]. In brackets for the main pillars the relevance factor and share of total score in $\%$

measures (e.g., species richness and diversity) but focuses mostly on greeneries and ratios of impervious surface. Moreover, this kind of assessments is limited to evaluate ecosystems on the base of their performance and services, yet neglecting biogeographic factors such as the real and the potential species and habitat distribution patterns (similarly to what happens in the case of several green roofs guidelines, see [109]). Besides, these indicators are poorly linked to the environment at a larger scale, thus strongly limiting their ecological reliability and their ability in contributing to Aichi's goals. Similarly, there would be the need to adding indicators accounting for the ecological niches offered by the whole building (i.e., not only green roofs and green wall) and to consider the effect of neighbouring semi-natural habitats on built-up areas.

\section{ICT-Enabled Design Processes}

Cities are considered a configuration of relationships, whose knowledge is more important than the elements that determine it [11]. The shift of focus from elements to relationships does not happen easily, because while elements can be quantified, measured and weighted, relationships need to be mapped. This is what we call pattern. Mapping relationships and studying patterns implies a qualitative, more than a quantitative, approach. In a holistic approach, the

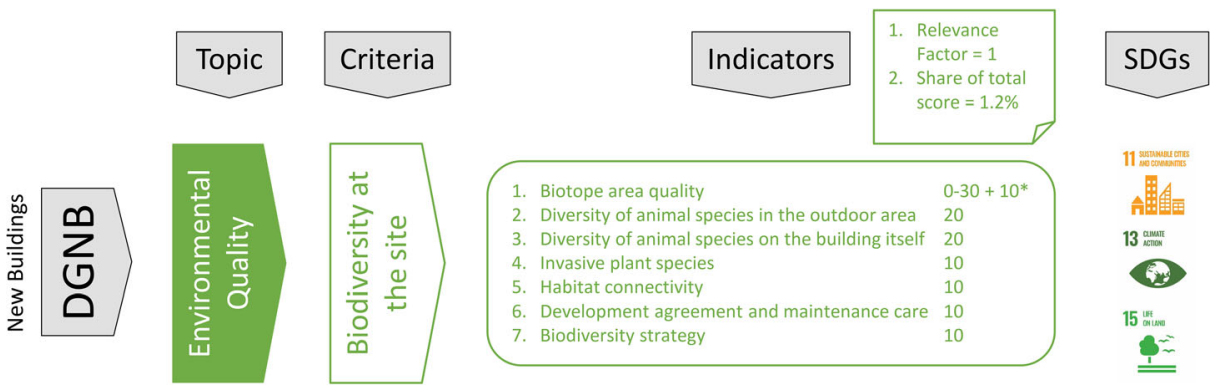

Fig. 6 Indicators for the biodiversity at the side criteria (DGNB). *Additional 10 points bonus available if further sustainable targets are fulfilled (Agenda 2030 bonus — climate and species protection goals) 
transition from quantity to quality is therefore implicit, as well as from structural elements to processes and interaction between the elements of the urban ecosystem. These interactions have been neglected in the sustainability assessments and their integration requires a radical change of perspective and a consequent revision.

\section{GeoBIM-Embedded Ecological Modelling: the Challenge of Integrating Biodiversity in Designing Frameworks}

Ecological models such as species distribution models (SDMs) are GIS-oriented tools inspired by the species-environment relationship. In fact, SDMs predict species distribution across the landscape combining species occurrence/absence (or abundance) with estimated environmental factors including land cover classification [140]. SDMs cover various tools and approaches which could be deployed depending on the ecological question users may answer. For example, MAXENT may only require basic information such as simple occurrence maps and abiotic variables to predict habitat suitability for the considered species [141], while more comprehensive approaches like environmental niche models (also known as bioclimatic modelling or envelope modelling) are able to predict species presence and abundance or colonisation patterns [142-144] (Fig. 7).

However, SDMs provide relevant information only on the habitat suitability but not on the species population dynamics, which can be addressed by using complementary modelling approaches based on population viability analysis (PVA). PVA aims at predicting metapopulation functioning and is used since the 1980s for conservation planning (reviewed in [145]). Modern PVA models are individual based and spatially explicit, so they permit to estimate population viability and size but also flow rate of individuals [23, 146, 147], and sometimes even the flow rate of genes [23, 148]. The BIM-oriented functionalities, such as complex data management and simulation (embedded within GeoBIM), would automatize or semi-automatize crucial steps of ecological modelling such as the complex data management (e.g., local and/or external storage, IoT-based survey and satellite imagery) and model parameterization [149].

The possibility of using BIM data in a GIS context for designing with nature is crucial for the development of smart sustainable projects. As reviewed by Carvalho et al. [150], there are several BIM tools for green building design and sustainability certifications. Early studies promote BIM processes and tools to manage environmental and biodiversity issues at the landscape scale $[149,152]$, but there is a lack of data models to enable BIM dimensions for geospatial and temporal landscape analysis [153]. The integration of BIM with GIS (known as GeoBIM) has matured [154] and supports sustainable development through accurate urban analysis. By using geospatial information with BIM, policymakers, landscape and urban planners, as well as real estate owners/investors, can make truly ecologically responsible decisions during the lifecycle, not only predicting the energy performance. The benefits of GeoBIM analysis of the abiotic conditions are already acknowledged by real estate developers. Moreover, ecological modelling embedded in GeoBIM would also facilitate the interoperability between tools and, more importantly, improve the ability of the other GeoBIM users such as planners or designers to integrate the modelling predictions to their conventional designing process $[155,156]$. For example, to analyse the project impact on the surroundings, to better understand where and when the building will overheat, to plan and estimate the total amount of solar energy, etc. However, a gap has been identified in integrating the biotic environmental data to be used in a design project. 


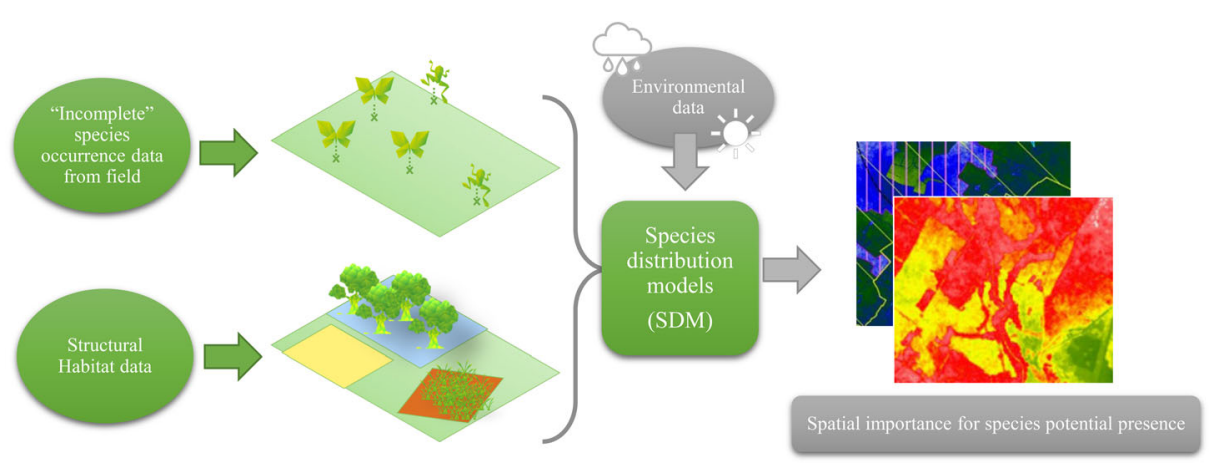

Fig. 7 General workflow of species distribution models. As inputs of the SDM there are land use and field sampling data; as outputs maps of spatial probability of species presence (from red to green).

\section{Digital Twins for Smart Cities—-the Potential for Integrating Biodiversity in a Geodesign Perspective}

The evolution of environmental design and planning is geodesign [157]. According to Ervin [158]: "Geodesign enhances traditional Environmental planning and Design activities with the power of modern computing, communications and collaboration technologies, providing ondemand simulations and impact analyses to provide more effective and more responsible integration of scientific knowledge and societal values into the design of alternative futures. [Moreover] The technical infrastructure for geodesign has been achieved by using the tools of existing GIS, CAD and BIM systems, coupled with spreadsheets, databases and emergent web techniques. This ad-hoc approach has not been altogether satisfactory, as there are still many interoperability issues to resolve; and, perhaps more critical, there is still considerable debate about whether and how design is supported and enabled (or thwarted) by these existing tools".

Digital twin systems are the most evolved ICT solutions which have proven their benefits in the development of sustainable smart cities such as cost efficiency [155] and increased collaboration. Digital twins of the built and natural environment start to emerge in different countries driven by government initiatives [159]. Grieves [160] first describes the digital twin in 2003 as a virtual, digital equivalent to a physical product which mirrors a real-life object, process or system. According to [161], in order to create a digital twin three main rules should be met: first, having the physical built components in real space; second, the virtual built components in virtual space and third, ensuring a real-time connection of data and information connects the virtual with the real building. Digital twin could be implemented with further layers including biodiversity-related information.

The interoperability issues are being solved in the common data environment (CDE) enabled by open BIM data standards such as Industry Foundation Classes (IFC), which is a recent approach yet unexploited in the context of designing with nature $[149,162]$. Open BIM creates new opportunities for applications and services because the integration of technologies such as laser scanning, extended reality (XR) — which includes virtual, augmented and mixed reality — data analytics, GIS, Internet of Things (IoT) and blockchain with BIM. For example, as proposed by de Laat and van Berlo [163], the CDE can connect the GIS data of the local context with BIM. In this regard, within the BioBIM project, Moulherat et al. [149] developed a BIM demonstrator (technological prototype) integrating features dedicated to the planning/ management of environmental measures and focusing on (1) the integration of standard data 
from environmental assessments and monitoring of environmental measures, (2) the integration of numerical simulation data related to animal and plant population dynamics and (3) the integration of plant growth simulation and landscape dynamics data (relevant for the management of the green infrastructure).

\section{Computation and Automatization in Urban and Architectural Design}

Computational design is getting increasing attention among architects and planners [164]. Nevertheless, when it comes to definitions (as in the case of smart cities), there is the frequent confusion among terms which were adopted before being truly settled and deeply investigated. In other words, what is the relationship between generative design (GD) and parametric design (PD)? Is it possible to use the two terms interchangeably?

$\mathrm{PD}$ in synthesis is "a design process based on algorithmic parameters and rules to constrain them"; likewise, BIM establishes "dependencies among different design elements", turning them into "symbolic parameters that have specific domains" [164]. This approach allows the designers to change the final design by changing defined parameters. GD was defined as a "design paradigm that employs algorithmic descriptions" [164] that compared to PD are more autonomous, namely, rely less on the user, and are set in an evolutionary context. In fact, according to Frazer et al. [165], GD and evolutionary design use computers as virtual space "in a manner analogous to the evolutionary process in nature". In the urban context, parametric urbanism (PU) emerged to give solutions in the context of complex urban development projects [166]. Its origins can be traced back to the 1970s when the first definitions of generative systems were formulated [167]. Christopher Alexander was one of the first to come up with a GD approach using more than 250 patterns and subpatterns organised so to create a systematic method: the pattern language $[167,168]$. Recent ICT developments are causing the shift from urban parametric design towards GD systems by integrating machine learning and applying artificial intelligence to enable several alternative design solutions to be generated by different sets of parameters [169].

In the last two decades, bioclimatic architecture and design experienced remarkable progress driven by a broader designer (and social) interest towards sustainability issues and enabled by the latest ICT advances. In the early 1990s, the eco-design stepped beyond the simple resource-saving approach towards the environmental efficiency one, intending to reduce the impact that buildings and human activities had on the natural environment (nature-conscious design) [170]. In this scenario, architectural generative eco-design aims at finding low-environmental impact solutions based on the spatial bioclimatic contexts, combining in a multidisciplinary way architecture, ecology and engineering. The synergy among multiple disciplines is possible thanks to computing technologies enabling designers to cope - at early-stage phases - with high levels of complexity, for example, enabling them to run sophisticated LCA or integrate interactive and generative processes employing evolutionary design tools [171]. The first software enabling to integrate LCA targets in the upstream phase using a generative approach is the VizCab@) software, developed at the Polytechnic University of Lausanne (EPFL) $[170,172]$. By integrating BIM with LCC and LCA the application of these types of sustainability analysis in the early stages of a project becomes possible [52, 173, 174].

In the context of performance-oriented design, VizCab offers a LCA-based data-driven design method based on the "combination of LCA, parametric analysis, data visualisation, sensitivity analysis, and target cascading techniques" [175]: to make the most efficient and 
sustainable choice, the user first sets the overall hierarchical targets and constrains (e.g., that of the 2000-watt society vision); then, the software assesses each sub-target (target-cascading technique), followed by the visualisation of multicriteria graphics (parallel coordinates data visualisation), which allows the user to check the impact that certain parametric choices have on the environmental targets (parametric analysis). This process is replicated several thousand times in feedback loops to feed the design alternative database (also knowledge database) which is eventually queried on a sensitive analysis base; this kind of analysis explores only among the most sensitive and relevant solutions $[175,176]$. The strength of the LCA method is that it is site specific and provides guidance at the beginning of the design process (with few details); nevertheless, the software is still in a prototyping stage and the visualisation of the knowledge database is not very user-friendly [176]. Attempts to solve the latter issue were made using Rhinoceros@ and Grasshopper@ graphical algorithm editor, whilst emissions and other physical analysis were simulated with other Rhinoceros plug-ins, i.e., Ladybug (analysis of climate data) and Honeybee (daylight simulations) (Fig. 8) [177-179].

The centrality of computing engine interface and architects is instead one of the priorities of the generative eco-design tool EcoGen $\odot$, which combines the computational generative process with architect's cognitive one $[180,181]$. This software resulted as the output of the Generative Eco-Design project (Eco-Conception Générative) (2011-2012, funded by the French National Research Agency (Agence Nationale de la Recherche, ANR)) initially involving the National School of Architecture of Lyon (MAP-ARIA) and Nancy (MAP-CRAI) and the University of Nancy 2 (Codisant-Sitcom, Interpsy) [181]. The software is under constant upgrade [171], and it is thought to support the designers in the sketch phase by proposing several set-into-context solutions, as in the VizCab software, computed on the base of efficiency analysis. The software engine optimises bioclimatic, ecological and economic criteria to the local context: urban (plot of land and surrounding blocks), environmental (climate-solar model) and programmatic (urban planning rules, e.g., buildable area and distance from roads). The computation is based on population evolution which uses one morphological engine and a genetic one in a systemic loop (morphogenesis, evaluation and optimization), thus generating random families of solutions (Fig. 9). In the assisted interactive mode, the software let the designers/users select the most suitable solution in different steps on the base of a subjective choice (e.g., aesthetic) or objective (e.g., functional) so that the whole generative process is also driven by user-specific choices.

Performance-based or -oriented design (PeD) is also an emerging approach based on computational information boosts; nevertheless, when compared with PD and GD, it is not yet quite in use [164]. Probably, the most representative examples of PeD are given by the Oslo School of Architecture and Design, intended also as a data-oriented design [182]. In their methodology, Hensel and Sørensen [183] merge computational-based design with system thinking intending to link architecture with the local setting, both environmental and cultural (patterns of space and land use) on both multiscale and multivariate bases. For example, the
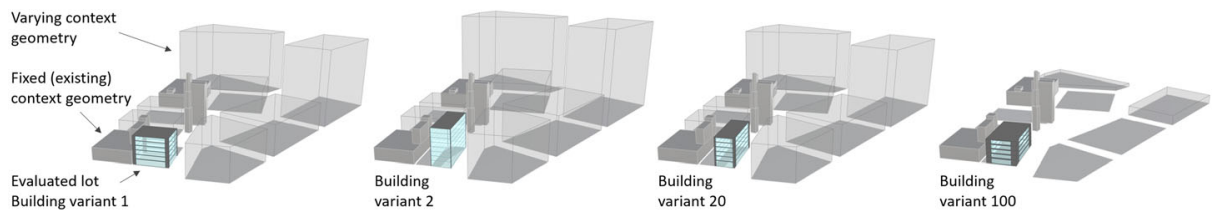

Fig. 8 Examples of the buildings alternatives automatically generated with the integration of Rhinoceros and Grasshopper (from [177]). Original figures: courtesy of the authors 


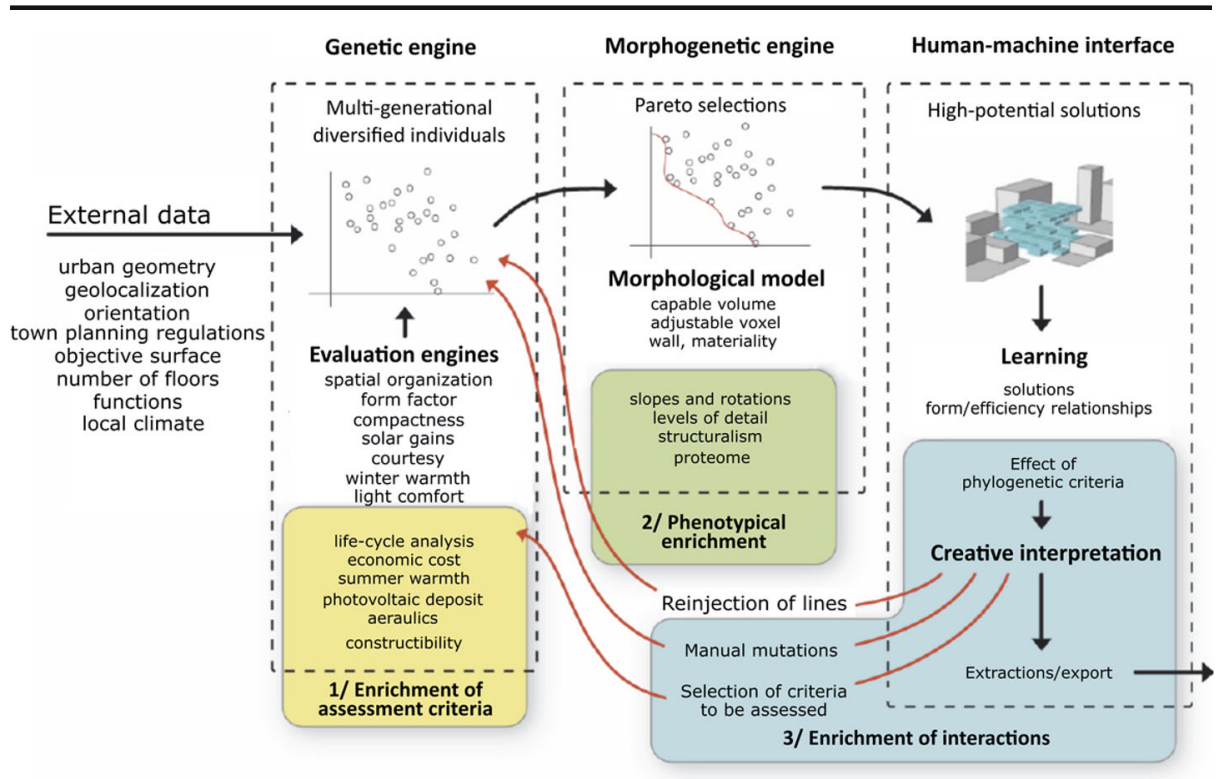

Fig. 9 Conceptual functioning of the EeoGen2 generative eco-design tool (from [181])

case study of developing low-rise and high-density settlement along the Oslo Fjord responded to the aim of solving the research line inquiry to design areas at the urban edge, focusing on local bio-physical conditions. Key environmental parameters (feeding the associative model, see [184]) were the slope, the substrate, the water run-off and the sensitive habitats. Evolutionary algorithmic methods were used to find the best solution followed by analysis and rate.

The new developments in PD, GD, and PeD, identified in this review, shed light on the potential integration of context-specific biodiversity figures (e.g., derived from species distribution models) in the early stage of the design process (vs. post-design optimisation).

\section{Synthesis: the DeMo Framework}

\section{Towards the Integration of Habitats in the Built Environment}

Modern cities consist of a meta-network of complex technologies and interactions, involving many feedback switches that operate far from equilibrium and produce a variety of emerging properties. The innovativeness, adaptability and carrying capacity of urban networks is a prerequisite of smart sustainable cities. However, among the emerging properties of modern cities, there is no temporal stability, which is a fundamental property of natural ecosystems. Processes and interactions of the urban ecosystem are so fast and involve such a multitude of sources that it is extremely difficult to control and predict emerging properties. However, the sustainable city, as promoted by The Aalborg Charter [186], looks like an ecological modernization of planning criteria, a kind of greenwashing unable to veer towards new paradigms.

Projects not mediated by a site-based scientific ecological knowledge, projects neglecting the importance of integrating local habitats and biodiversity in the built environment, will perhaps be able to create better housing solutions but will not change the relationship of a city with the surrounding nature, landscape and ecosystems. The smart sustainable city, instead, should be a 
resilient city, with a reduced ecological footprint and with a strong relationship with the local ecosystems (which define the reference eco-region). Perhaps, before planning and constructing new cities or new districts (such as the Vauban district in Freiburg, Bedzed in Sutton, Houten in Utrecht and Dongtan in Shanghai), architects and planners should first focus on how to inhabit the existing cities differently.

"The city, which for centuries has operated according to the formula of the "place where everything is exchanged', should become Noah's ark destined to ensure the survival of the species despite the flood. A great autonomy, a great autarchy will therefore be necessary" [187]. Ecological research teaches us that a wide array of forms and functions (i.e., what we call "biodiversity") is the only way for ecosystems to perpetuate themselves over time and to adapt to environmental changes. For a smart and sustainable development of cities, this translates, first, into a change in the habits of those who live there, and the acceptance of interventions aimed at integrating natural habitats in the built environment. In the DeMo project, the development of a holistic workflow has tried to respect the basic principles of ecosystem functioning and, therefore, has some characteristics in common with natural ecosystems: it is deeply rooted to places and the local scale, is energy conscious and community oriented.

\section{The Integration of SDGs and Aichi's Biodiversity Targets in the DeMo Framework}

The DeMo framework is anchored in both the SDGs and Aichi's targets, tackling them at different levels and degrees. Some of the focal targets shaping DeMo vision are resiliency, participation, traditional knowledge and of course as core target; biodiversity conservation as deepened in the next paragraph focused on the framework (Fig. 10).

\section{Resiliency}

In simple words, a system is resilient if it can withstand or come back to the original equilibrium and health after the ceasing of the disturbance factor(s) [188-191]. Considering highly urbanised ecosystems, it is utopic to believe that they can be resilient enough to come back to their equilibrium before urbanisation itself. In our vision, however, greening urbanised systems should contribute to change them towards a more biodiversity-favourable equilibrium, contributing, thus global Aichi's goal of no net biodiversity loss (NNL) [44, 192].

\section{Participation}

New participative designing ways, such as system-oriented design (SOD), have been developed and used in the last years in Northern Europe to disentangle complex systems collaboratively (e.g., in groups of experts, users and stakeholders) [193, 194]. Central to SOD are gigamaps and the innovative representation and understanding of the relationships among the parts; these relationships types, yet not dogmatic [194], are included in the library of systemic relations (e.g., structural, semantic and casual). Here, we refer to this approach as inspiration to merge designers'/planners' perspective with that of ecologists who are not yet sufficiently integrated into this framework leading to the under-representation of biodiversity management during the infrastructure design [43, 195]. 


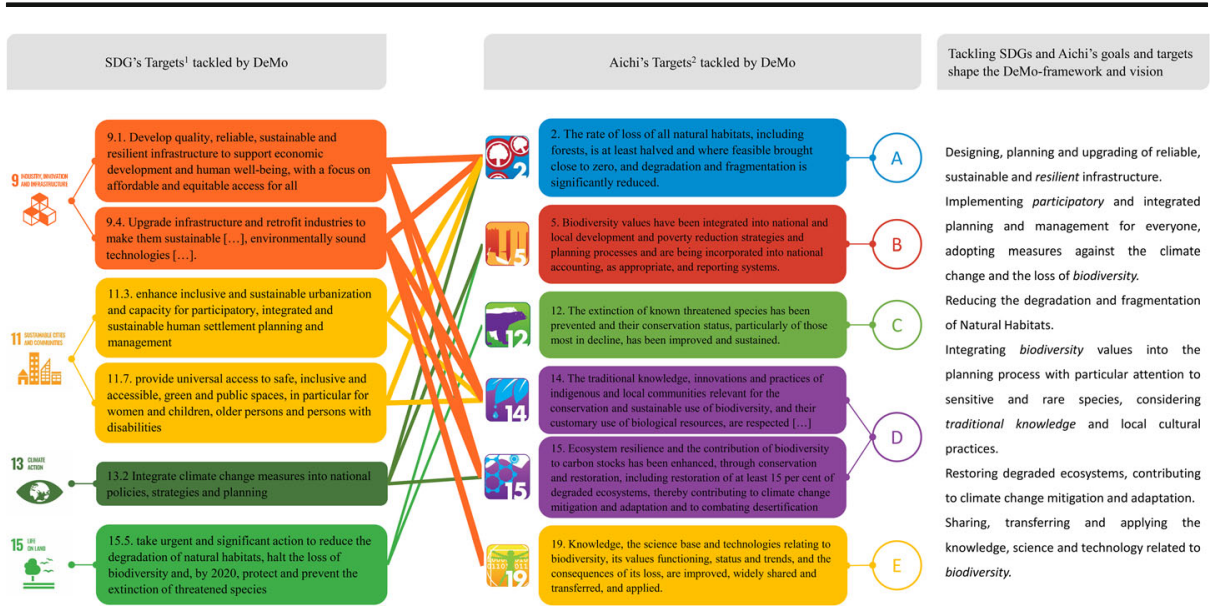

Fig. 10 Selection of SDGs [7] and Aichi's target [9] tackled by the DeMo framework. Thicker lines join targets and goals tackled the most by the project. ${ }^{1}$ Sustainable development goal-icons: United Nations/globalgoals.org; ${ }^{2}$ Aichi's target logos. Copyright BIP/SCBD

\section{Traditional Knowledge}

Some researchers have identified conflicts intrinsic to SDGs when it comes for instance to building efficiency (goals 9 and 11) and biodiversity conservation targets (goal 15). For example, in a study case investigating 104 villages in Poland, the abundance of building-nesting birds declined at about $50 \%$ due to building modernization and renovation [196]. The Polish example suggests that to mitigate this alarming and underestimated phenomenon, designers should build innovative and birdfriendly houses taking inspiration from traditional architecture. For this reason, setting up the ecological network of protected areas and corridors connecting them [197-200], it will be not enough to obtain resilient systems, but it is also important to reduce the pressure on ecosystems [201] and to change the way we plan our cities and understand human society [202]. In our case, traditional and vernacular architectures [203] and other traditional spontaneously colonised manmade structures will be looked-up to inspire the design.

\section{The Holistic Framework: from Design with Nature to Design for Nature}

In this paper, we highlighted that biodiversity in its complexity is poorly integrated into the current practices of both the sustainable evaluation of cities and buildings. Nevertheless, we assist to a growing demand by inhabitants and governmental institutions to meet the sustainability targets and the growing involvement of ecologists to obtain more nature in the city [204]. In fact, ecologists are pledging for a planned efficient integration of biodiversity issues in landscape and city planning [50] as well as for the design of biodiversity-friendly building [43]. To this regard, the development of large-scale ecological modelling allows us to handle and take into account the complexity of biodiversity and biological processes [45, 205].

Here, we forecast a new horizon where also ecology is considered in the architecture, engineering, and construction industry, which becomes nature, architecture, engineering and construction (NAEC). The DeMo framework shall consider, on the one hand, the expectation of conservation biologists to better integrate biodiversity features in cities and buildings, on the other hand, that planners and designers are willing to rewild cities and increase human well-being. This shift from 
design with nature to design for nature (Fig. 11) is inspired by the designing practices of geodesign [16] and the Design with Nature of McHarg [14], by landscape-specific conservation planning practices [26, 46, 48], reserve site selection [40, 41] and current target-based approaches [206, 207]. The framework takes into account the three components of biodiversity, as described in Noss [208]:

1) The composition: component corresponds to a list of genes, species, habitats, ecosystems, etc. It is a catalogue of elements found in the object under study.

2) The structure: component deals with the physical organisation of elements (distance from one to another, habitat aggregation, etc.).

3) The function: component relates to processes and ecological dynamics underpinning the common understanding of ecosystem services and ecological functionalities.

To transform artefacts (e.g., constructions, buildings and walls) into suitable habitats for some species, several criteria must be fulfilled [88, 198, 209-213]:

(1) Provision of favourable microhabitats, enough food, appropriate shelters, etc. (validated thanks to SDM)

(2) Connection with the local ecological network to permit species settlement and ensure their persistence in these habitats (proved by PVA)

In this respect, the BIM-embedded modelling process will allow us to determine whether artefacts are as follows:

(1) Suitable for targeted species (the habitat niches are favourable)

(2) Integrated into the ecological network and thus susceptible to be colonised

(3) Viable habitats for targeted species thanks to their suitability and/or their appropriate integration in the ecological network

To overcome the limitations derived by the complexity of the analytical process needed to properly integrate the biodiversity component into architectural design and urban planning, the DeMo framework is multidisciplinary, holistic and is enabled by ICT tools. At the local scale, our process would permit to test/simulate scenarios related to real/virtual constructions, while determining at the large-scale the design which best fits the biodiversity management goals [41, 46]. This evaluation should be done for each building and design scenario, iteratively so to optimise the overall workflow and get to the final design. At the landscape scale, the procedure will also permit us to determine the potential of green buildings to become refuges for some species [214-218]. To this respect, thanks to embedded parametric modelling, GeoBIM already allows the comparison of multiple design solutions at the beginning of a project [219] or provide constraints like in the case of building permit [220]. Furthermore, algorithmic and parametric design tools, used in conjunction with the GeoBIM process, would allow to generating alternative solutions [221] stimulating designers creativity [180].

Crucial phases of the DeMo framework are (Fig. 12) as follows:

(1) Retrieving and processing biotic and abiotic data at multiple scales and resolutions fitting the ecological modelling tasks and objectives (strategic planning project and design definition) 


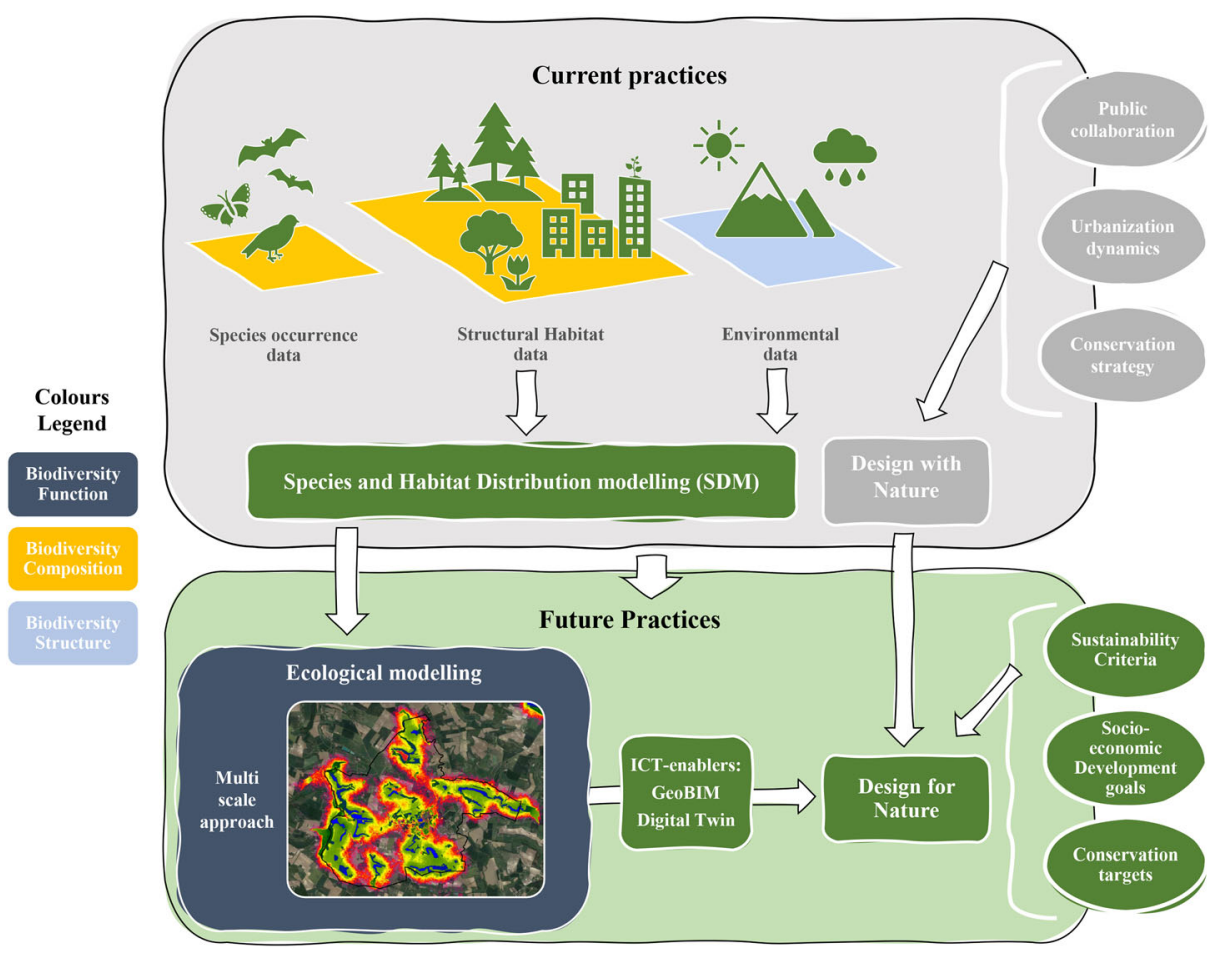

Fig. 11 The workflow leading from the current practices design with nature to design for nature at multiple scales

(2) Processing and implementing the ecological data at urban/municipality and building scales in a feedback-loop workflow with ecological modelling at small scale

(3) Selecting the best designing solution fitting both sustainable development goals and biodiversity targets

(4) Monitoring of wild plant and animal species behaviour and dynamic with respect to the created ecological niches (e.g., on building walls and roofs), with the final aim to feed the parametric and ecological design feedback loop

\section{Concluding Remarks}

Discipline territorialities are difficult to cross but can truly profit one from each other in multidisciplinary projects. This seldom happens, either because of perspective conflicts (development vs. conservation for example), or because the society where we live nowadays forges highly specialised individuals. The intent of this paper is to pile up the pool of knowledge serving not only as a basement of the multidisciplinary DeMo framework (allowing, for example, architects and conservation biologists to merge their standard workflows) but also to streamline the tools and disciplines that would boost the integration of the biological conservation targets in the practice of architectural design and urban planning. Thus, the examples we brought in this paper may prove to be useful, on 


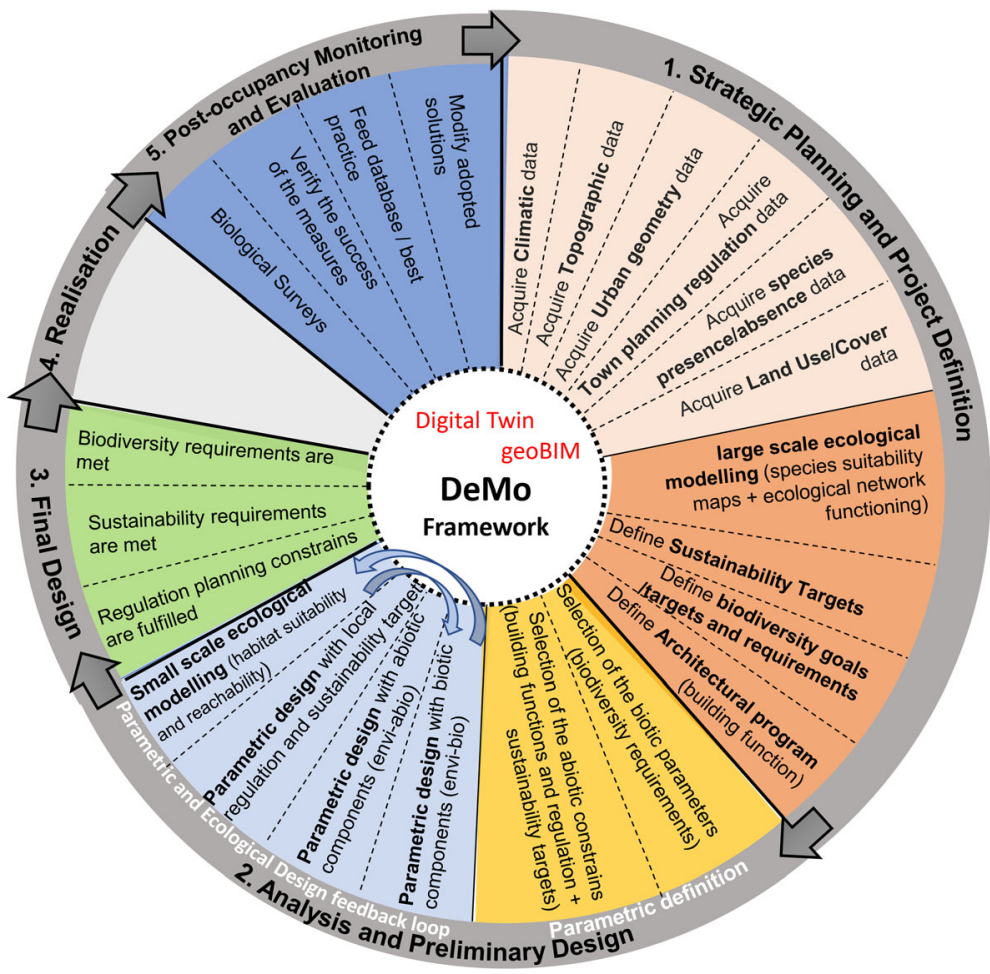

Fig. 12 DeMo framework hierarchical steps and feedback-loop relationships

the one hand, to inspire and feed the DeMo project workflow, and on the other hand, to identify overlooked synergies and cooperation opportunities.

So, in simple words, if it is possible to simulate the movement of an insect depending on the complex plant architecture and morphogenesis [222], it must be possible, indeed easier, to do the same depending on parametric architectural models. Thus, playing with Goddard et al.'s [223] words, we envision to design wildlife-friendly buildings connected to gardens and surrounding open green spaces. Mainstreaming building design and biodiversity conservation strategies via landscape and urban biodiversity-informed planning (Design for Nature) has the potential to strongly contribute to the Aichi target [224]. Indeed, McHarg's intuition that ecological knowledge shall play a fundamental role to educate contemporary society proved to be right. Fortunately, his philosophy is still traceable in significant education initiatives such as the schools for ecoliteracy $[225,226]$ and in new curricula development aiming at merging design with ecology [227].

The first study case of DeMo, not presented here, will be the University Campus of the Zurich University of Applied Science (ZHAW) in Wädenswil (Switzerland) and will be the focus of a forthcoming research paper.

Acknowledgements The authors thank Salvatore Pasta (Institute of Bioscience and BioResources (IBBR) of the Italian National Council of Research (CNR)-Unit of Palermo) and two anonymous reviewers for their valuable comments, which improved the final version of the paper. 
Author Contribution $\mathrm{CC}$ led the paper writing with substantial contributions of MM, SM and JB. CC, MM and SM conceived the paper and run its critical revisions. CC, MM, NB, SD and SM obtained the grant. All the authors contributed to the paper revision and approved the final version.

Funding Open Access funding provided by ZHAW Zürcher Hochschule für Angewandte Wissenschaften. The DeMo Project is financed by the Zurich University of Applied Science (ZHAW) to support the multidisciplinary and inter-institutional research on environmental issues (Campus@LSFM, duration of the project 2020-2021). This work also contributes to the CONAQUAT research and innovation project grant by the French Region Occitanie.

Data Availability Not applicable.

Code Availability Not applicable.

\section{Declaration}

Conflict of Interest On behalf of all co-authors, Chiara Catalano as the corresponding author declares that there is no conflict of interest among them.

Open Access This article is licensed under a Creative Commons Attribution 4.0 International License, which permits use, sharing, adaptation, distribution and reproduction in any medium or format, as long as you give appropriate credit to the original author(s) and the source, provide a link to the Creative Commons licence, and indicate if changes were made. The images or other third party material in this article are included in the article's Creative Commons licence, unless indicated otherwise in a credit line to the material. If material is not included in the article's Creative Commons licence and your intended use is not permitted by statutory regulation or exceeds the permitted use, you will need to obtain permission directly from the copyright holder. To view a copy of this licence, visit http://creativecommons.org/licenses/by/4.0/.

\section{References}

1. Haddad NM, Brudvig LA, Clobert $\mathbf{J}$ et al (2015) Habitat fragmentation and its lasting impact on Earth ecosystems. Sci Adv 1:e1500052. https://doi.org/10.1126/sciadv.1500052

2. Keil P, Storch D, Jetz W (2015) On the decline of biodiversity due to area loss. Nat Commun 6:8837. https://doi.org/10.1038/ncomms9837

3. Pereira HM, Navarro LM, Martins IS (2012) Global biodiversity change: the bad, the good, and the unknown. Annu Rev Environ Resour 37:25-50. https://doi.org/10.1146/annurev-environ-042911-093511

4. Liotta C, Kervinio Y, Levrel H, Tardieu L (2020) Planning for environmental justice - reducing well-being inequalities through urban greening. Environ Sci Policy 112:47-60. https://doi.org/10.1016/j.envsci.2020. 03.017

5. Ta M-T, Tardieu L, Levrel H (2020) Characterising the demand side of urban greening to inform urban planning CIRED Working Paper 2020-78- Février 2020. 51

6. Griggs D, Stafford-Smith M, Gaffney O, Rockström J, Öhman MC, Shyamsundar P, Steffen W, Glaser G, Kanie N, Noble I (2013) Sustainable development goals for people and planet. Nature 495:305-307. https://doi.org/10.1038/495305a

7. UN (2015) Transforming our world: the 2030 agenda for sustainable development. UNITED NATIONS

8. Rosa W (2017) A new era in global health. nursing and the united nations 2030 agenda for sustainable development. Springer Publishing Company, New York, NY

9. UNEP (2016) Biodiversity and the 2030 agenda for sustainable development. Technical Note. Convention on Biological Diversity, Montreal, Quebec, Canada H2Y 1N9

10. IPBES (2019) Summary for policymakers of the global assessment report on biodiversity and ecosystem services. IPBES

11. Odum EP (1993) Ecology and our endangered life-support systems. Sinauer Associates, Sunderland, Mass

12. Odum EP (1985) Ecology: the link between the natural and the social sciences. Holt, Rinehart and Winston, London 
13. Bryant MM, Turner JS (2019) From thermodynamics to creativity: McHarg's ecological planning theory and its implications for resilience planning and adaptive design. Socio-Ecol Pract Res 1:325-337. https:// doi.org/10.1007/s42532-019-00027-1

14. McHarg IL (1969) Design with nature. Natural History Press, New York

15. Li W, Milburn L-A (2016) The evolution of geodesign as a design and planning tool. Landsc Urban Plan 156:5-8. https://doi.org/10.1016/j.landurbplan.2016.09.009

16. Steinitz C (2012) A framework for geodesign: changing geography by design. Esri, Redlands, Calf

17. Rabiye Z, Selim S, Karakuș N, Cinar İ (2020) GIS-based approach to determine suitable settlement areas compatible with the natural environment. J Environ Sci Manag 23:71-82

18. Tarabon S, Calvet C, Delbar V et al (2020) Integrating a landscape connectivity approach into mitigation hierarchy planning by anticipating urban dynamics. Landsc Urban Plan 202:103871. https://doi.org/10. 1016/j.landurbplan.2020.103871

19. Calvet $\mathrm{C}$, Delbar V, Chapon $\mathrm{P}$, et al (2020) La biodiversité à l'épreuve des choix d'aménagement : une approche par la modélisation appliquée à la Région Occitanie. 31:8

20. Aspinall R J (1994) GIS and spatial analysis for ecological modelling. In: Michener WK, Brunt JW, Stafford SG (eds) Environmental Information Management And Analysis : Ecosystem To Global Scales. CRC Press, pp 403-422

21. Fedra K (1993) GIS and environmental modeling. In: Goodchild MF, Parks BO, Steyaert LT (eds) Environmental modeling with GIS. Oxford University Press, New York, pp 35-50

22. Wegmann M, Leutner B, Dech S (2016) Remote sensing and GIS for ecologists: using open source software. Pelagic Publishing Ltd

23. Moulherat S (2014) Toward the development of predictive systems ecology modeling: MetaConnect and its use as an innovative modeling platform in theoretical and applied fields of ecological research. Université de Toulouse, Université Toulouse III-Paul Sabatier

24. Lystra M (2016) Drawing natures: US highway location, representational techniques and the rise of ecological design. J Des Hist. 30(2):157-174. https://doi.org/10.1093/jdh/epw013

25. Herrington S (2010) The nature of Ian McHarg's science. Landsc J 29:1-20. https://doi.org/10.3368/lj.29. 1.1

26. Margules CR, Pressey RL (2000) Systematic conservation planning. Nature 405:243-253. https://doi.org/ $10.1038 / 35012251$

27. Business and Biodiversity Offsets Programme (BBOP) (2012) Biodiversity offset design handbookupdated. BBOP, Washington, D.C.

28. Clare S, Krogman N, Foote L, Lemphers N (2011) Where is the avoidance in the implementation of wetland law and policy? Wetl Ecol Manag 19:165-182. https://doi.org/10.1007/s11273-011-9209-3

29. Phalan B, Hayes G, Brooks S et al (2018) Avoiding impacts on biodiversity through strengthening the first stage of the mitigation hierarchy. Oryx 52:316-324. https://doi.org/10.1017/S0030605316001034

30. Weissgerber M, Roturier S, Julliard R, Guillet F (2019) Biodiversity offsetting: certainty of the net loss but uncertainty of the net gain. Biol Conserv 237:200-208. https://doi.org/10.1016/j.biocon.2019.06.036

31. Bezombes L, Kerbiriou C, Spiegelberger T (2019) Do biodiversity offsets achieve no net loss? An evaluation of offsets in a French department. Biol Conserv 231:24-29. https://doi.org/10.1016/j.biocon. 2019.01.004

32. Bull JW, Suttle KB, Gordon A et al (2013) Biodiversity offsets in theory and practice. Oryx 47:369-380. https://doi.org/10.1017/S003060531200172X

33. Calvet C, Napoléone C, Salles J-M (2015) The biodiversity offsetting dilemma: between economic rationales and ecological dynamics. Sustainability 7:7357-7378. https://doi.org/10.3390/su7067357

34. Arlidge WNS, Bull JW, Addison PFE et al (2018) A global mitigation hierarchy for nature conservation. BioScience 68:336-347. https://doi.org/10.1093/biosci/biy029

35. Birkeland J, Knight-Lenihan S (2016) Biodiversity offsetting and net positive design. J Urban Des 21:5066. https://doi.org/10.1080/13574809.2015.1129891

36. Curran M, Hellweg S, Beck J (2014) Is there any empirical support for biodiversity offset policy? Ecol Appl 24:617-632. https://doi.org/10.1890/13-0243.1

37. Ermgassen SOSE zu, Baker J, Griffiths RA, et al (2019) The ecological outcomes of biodiversity offsets under "no net loss" policies: a global review. Conserv Lett 12:e12664. https://doi.org/10.1111/conl.12664

38. Quétier F, Teeffelen AJAV, Pilgrim JD et al (2015) Biodiversity offsets are one solution to widespread poorly compensated biodiversity loss: a response to Curran et al. Ecol Appl 25:1739-1741. https://doi.org/ $10.1890 / 14-1217.1$

39. Kiesecker JM, Copeland H, Pocewicz A, McKenney B (2010) Development by design: blending landscape-level planning with the mitigation hierarchy. Front Ecol Environ 8:261-266. https://doi.org/ $10.1890 / 090005$ 
40. Kujala H, Whitehead AL, Morris WK, Wintle BA (2015) Towards strategic offsetting of biodiversity loss using spatial prioritization concepts and tools: a case study on mining impacts in Australia. Biol Conserv 192:513-521. https://doi.org/10.1016/j.biocon.2015.08.017

41. Kukkala AS, Moilanen A (2013) Core concepts of spatial prioritisation in systematic conservation planning: Concepts of systematic conservation planning. Biol Rev 88:443-464. https://doi.org/10.1111/ brv. 12008

42. Bigard C, Thiriet P, Pioch S, Thompson JD (2020) Strategic landscape-scale planning to improve mitigation hierarchy implementation: an empirical case study in Mediterranean France. Land Use Policy 90:104286. https://doi.org/10.1016/j.landusepol.2019.104286

43. Clergeau P (2020) Urbanisme et biodiversité: vers un paysage vivant structurant le projet urbain. Éditions Apogée, Rennes

44. Comte A, Kervinio Y, Levrel H (2020) Ecosystem accounting in support of the transition to sustainable societies - the case for a parsimonious and inclusive measurement of ecosystem condition. CIRED Work Pap

45. Pollock LJ, O’Connor LMJ, Mokany K, Rosauer DF, Talluto MV, Thuiller W (2020) Protecting biodiversity (in all its complexity): new models and methods. Trends Ecol Evol 35:1119-1128. https:// doi.org/10.1016/j.tree.2020.08.015

46. Gunton RM, Marsh CJ, Moulherat S et al (2017) Multicriterion trade-offs and synergies for spatial conservation planning. J Appl Ecol 54:903-913. https://doi.org/10.1111/1365-2664.12803

47. Kujala H, Moilanen A, Gordon A (2018) Spatial characteristics of species distributions as drivers in conservation prioritization. Methods Ecol Evol 9:1121-1132. https://doi.org/10.1111/2041-210X.12939

48. Simmonds JS, van Rensburg BJ, Tulloch AIT, Maron M (2019) Landscape-specific thresholds in the relationship between species richness and natural land cover. J Appl Ecol 56:1019-1029. https://doi.org/ 10.1111/1365-2664.13320

49. Kiesecker JM, Copeland H, Pocewicz A et al (2009) A framework for implementing biodiversity offsets: selecting sites and determining scale. BioScience 59:77-84. https://doi.org/10.1525/bio.2009.59.1.11

50. Milner-Gulland EJ, Addison P, Arlidge WNS et al (2021) Four steps for the Earth: mainstreaming the post2020 global biodiversity framework. One Earth 4:75-87. https://doi.org/10.1016/j.oneear.2020.12.011

51. KPMG (2018) The road to opportunity an annual review of the real estate industry's journey into the digital age

52. Meslec M, Ashworth S, Druhmann C (2018) Integrating life cycle sustainability analysis with BIM. In: 17th EFMC Research Symposium. Sofia, Bulgaria, pp 96-108

53. Wang H, Pan Y, Luo X (2019) Integration of BIM and GIS in sustainable built environment: a review and bibliometric analysis. Autom Constr 103:41-52. https://doi.org/10.1016/j.autcon.2019.03.005

54. PwC (2018) BIM benefits methodology and report. https://www.cdbb.cam.ac.uk/news/ 2018JuneBIMBenefits. Accessed 26 Jan 2021

55. Noardo F, Arroyo Ohori K, Biljecki F et al (2020) The ISPRS-EUROSDR GeoBIM benchmark 2019. In: ISPRS - International Archives of the Photogrammetry. Remote Sensing and Spatial Information Sciences, Copernicus GmbH, pp 227-233

56. Zari MP (2014) Ecosystem services analysis in response to biodiversity loss caused by the built environment. SAPIENS Surv Perspect Integrating Environ Soc 7(1):1-14

57. Shi X, Yang W (2013) Performance-driven architectural design and optimization technique from a perspective of architects. Autom Constr 32:125-135. https://doi.org/10.1016/j.autcon.2013.01.015

58. Birkeland J (2020) Net-positive design and sustainable urban development. Routledge

59. Tratalos J, Fuller RA, Warren PH et al (2007) Urban form, biodiversity potential and ecosystem services. Landsc Urban Plan 83:308-317. https://doi.org/10.1016/j.landurbplan.2007.05.003

60. Birkeland J (2008) Positive development : from vicious circles to virtuous cycles through built environment design. Routledge

61. du Plessis C (2012) Towards a regenerative paradigm for the built environment. Build Res Inf 40:7-22. https://doi.org/10.1080/09613218.2012.628548

62. Birkeland J (2009) Design for eco-services part A - environmental services. Environ Des Guide:1-12

63. Birkeland J (2009) Eco-retrofitting with building integrated living systems. In: van den Dobbelsteen A (ed) Proceedings of the 3rd CIB International Conference on Smart and Sustainable Built Environment. Delft University of Technology, Netherlands, pp 1-9

64. Bullock JM, Aronson J, Newton AC et al (2011) Restoration of ecosystem services and biodiversity: conflicts and opportunities. Trends Ecol Evol 26:541-549. https://doi.org/10.1016/j.tree.2011.06.011

65. Mitsch WJ (2012) What is ecological engineering? Ecol Eng 45:5-12. https://doi.org/10.1016/j.ecoleng. 2012.04.013

66. Ross MRV, Bernhardt ES, Doyle MW, Heffernan JB (2015) Designer ecosystems: incorporating design approaches into applied ecology. Annu Rev Environ Resour 40:419-443. https://doi.org/10.1146/annurevenviron-121012-100957 
67. Kowarik I (2011) Novel urban ecosystems, biodiversity, and conservation. Environ Pollut 159:1974-1983. https://doi.org/10.1016/j.envpol.2011.02.022

68. Puppim de Oliveira JA, Balaban O, Doll CNH et al (2011) Cities and biodiversity: perspectives and governance challenges for implementing the convention on biological diversity (CBD) at the city level. Biol Conserv 144:1302-1313. https://doi.org/10.1016/j.biocon.2010.12.007

69. Kowarik I, Fischer LK, Kendal D (2020) Biodiversity conservation and sustainable urban development. Sustainability 12:4964. https://doi.org/10.3390/su12124964

70. Apfelbeck B, Jakoby C, Hanusch M et al (2019) A conceptual framework for choosing target species for wildlife-inclusive urban design. Sustainability 11:6972. https://doi.org/10.3390/su11246972

71. Apfelbeck B, Snep RPH, Hauck TE et al (2020) Designing wildlife-inclusive cities that support humananimal co-existence. Landsc Urban Plan 200:103817. https://doi.org/10.1016/j.landurbplan.2020.103817

72. Weisser WW, Hauck TE (2017) Animal-aided design - using a species' life-cycle to improve open space planning and conservation in cities and elsewhere. bioRxiv 150359. https://doi.org/10.1101/150359

73. Itani M, Zein MA, Nasralla N, Talhouk SN (2020) Biodiversity conservation in cities: defining habitat analogues for plant species of conservation interest. PLoS One 15:e0220355. https://doi.org/10.1371/ journal.pone. 0220355

74. Lundholm JT, Richardson PJ (2010) Habitat analogues for reconciliation ecology in urban and industrial environments. J Appl Ecol 47:966-975. https://doi.org/10.1111/j.1365-2664.2010.01857.x

75. Kowarik I, von der Lippe M (2018) Plant population success across urban ecosystems: a framework to inform biodiversity conservation in cities. J Appl Ecol 55:2354-2361. https://doi.org/10.1111/1365-2664. 13144

76. Hobbs RJ, Higgs E, Hall CM (2013) Novel ecosystems: intervening in the new ecological world order. John Wiley \& Sons, Chichester, West Sussex ; Hoboken, NJ

77. Rosenzweig ML (2003) Win-win ecology: how the earth's species can survive in the midst of human enterprise. Oxford University Press, Oxford ; New York

78. Miller JR, Hobbs RJ (2002) Conservation where people live and work. Conserv Biol 16:330-337. https:// doi.org/10.1046/j.1523-1739.2002.00420.x

79. Couvet D, Ducarme F (2014) Reconciliation ecology, from biological to social challenges. Rev D'ethnoécologie. https://doi.org/10.4000/ethnoecologie.1979

80. Ikin K, Roux DSL, Rayner L et al (2015) Key lessons for achieving biodiversity-sensitive cities and towns. Ecol Manag Restor 16:206-214. https://doi.org/10.1111/emr.12180

81. Miller JR (2006) Restoration, reconciliation, and reconnecting with nature nearby. Biol Conserv 127:356361. https://doi.org/10.1016/j.biocon.2005.07.021

82. Parris KM, Amati M, Bekessy SA et al (2018) The seven lamps of planning for biodiversity in the city. Cities 83:44-53. https://doi.org/10.1016/j.cities.2018.06.007

83. Pickett STA, Cadenasso ML, Childers DL et al (2016) Evolution and future of urban ecological science: ecology in, of, and for the city. Ecosyst Health Sustain 2:e01229. https://doi.org/10.1002/ehs2.1229

84. Pickett STA, Boone CG, McGrath B et al (2013) Ecological science and transformation to the sustainable city. Cities 32:S10-S20. https://doi.org/10.1016/j.cities.2013.02.008

85. McGrath B, Pickett STA (2011) The metacity: a conceptual framework for integrating ecology and urban design. Challenges 2:55-72. https://doi.org/10.3390/challe2040055

86. Pickett STA, Cadenasso ML, McGrath B (2013) Resilience in ecology and urban design. Springer Netherlands, Dordrecht

87. Gonzalez A, Germain RM, Srivastava DS et al (2020) Scaling-up biodiversity-ecosystem functioning research. Ecol Lett ele.13456. https://doi.org/10.1111/ele.13456

88. Hanski I, Gilpin ME (1997) Metapopulation biology, ecology, genetics, and evolution. Academic Press, Inc

89. Pickett STA, Cadenasso ML, Baker ME et al (2020) Theoretical perspectives of the baltimore ecosystem study: conceptual evolution in a social-ecological research project. BioScience 70:297-314. https://doi. org/10.1093/biosci/biz166

90. Pickett STA, McGrath B, Cadenasso ML (2013) The ecology of the metacity: shaping the dynamic, patchy, networked, and adaptive cities of the future. In: Pickett STA, Cadenasso ML, McGrath B (eds) Resilience in ecology and urban design: linking theory and practice for sustainable cities. Springer Netherlands, Dordrecht, pp 463-489

91. Pickett STA, McGrath B, Cadenasso ML, Felson AJ (2014) Ecological resilience and resilient cities. Build Res Inf 42:143-157. https://doi.org/10.1080/09613218.2014.850600

92. Atanasova N, Castellar JAC, Pineda-Martos R, Nika CE, Katsou E, Istenič D, Pucher B, Andreucci MB, Langergraber G (2021) Nature-based solutions and circularity in cities. Circ Econ Sustain 1:319-332. https://doi.org/10.1007/s43615-021-00024-1 
93. Stefanakis AI, Calheiros CSC, Nikolaou I (2021) Nature-based solutions as a tool in the new circular economic model for climate change adaptation. Circ Econ Sustain 1:303-318. https://doi.org/10.1007/ s43615-021-00022-3

94. Clément G (2003) Manifeste du tiers paysage. Sujet/Objet, Paris

95. Gandy M (2016) Unintentional landscapes. Landsc Res 41:433-440. https://doi.org/10.1080/01426397. 2016.1156069

96. Rupprecht CDD, Byrne JA, Garden JG, Hero J-M (2015) Informal urban green space: a trilingual systematic review of its role for biodiversity and trends in the literature. Urban For Urban Green 14: 883-908. https://doi.org/10.1016/j.ufug.2015.08.009

97. Nassauer JI (1995) Messy ecosystems, orderly frames. Landsc J 14:161-170. https://doi.org/10.3368/lj.14. 2.161

98. Kühn N (2006) Intentions for the unintentional: spontaneous vegetation as the basis for innovative planting design in urban areas. J Landsc Archit 1:46-53. https://doi.org/10.1080/18626033.2006.9723372

99. Lagurgue X, Mayrand F, Clergeau P (2019) Typologie de l'implantation de la flore spontanée en ville dense,: regard croisé écologue-architecte. VertigO. https://doi.org/10.4000/vertigo.25986

100. Francis RA, Lorimer J (2011) Urban reconciliation ecology: the potential of living roofs and walls. J Environ Manag 92:1429-1437. https://doi.org/10.1016/j.jenvman.2011.01.012

101. Calheiros CSC, Stefanakis AI (2021) Green roofs towards circular and resilient cities. Circ Econ Sustain 1: 395-411. https://doi.org/10.1007/s43615-021-00033-0

102. Gunnell K, Murphy B, Williams C (2019) Designing for biodiversity: a technical guide for new and existing buildings, 2nd edn. Riba Publishing. https://doi.org/10.4324/9780429347658

103. Birkeland J (2009) Communicating ecologically positive development. In: Wood P, Smitheram J (eds) Proceedings of the 5th International Conference of the Association of Architecture Schools in Australasia (AASA). The Association of Architecture Schools in Australasia, New Zealand, pp 1-10

104. Yeang K, Powell R (2007) Designing the ecoskyscraper: premises for tall building design. Struct Des Tall Spec Build 16:411-427. https://doi.org/10.1002/tal.414

105. Callebaut V (2015) Lilypad: floating ecopolis for climatical refugees. In: Wang CM, Wang BT (eds) Large floating structures: technological advances. Springer, Singapore, pp 303-327

106. ChartierDalix (2019) Accueillir le vivant: l'architecture comme écosystème [Hosting life: architecture as an ecosystem]. Park Books, Zürich

107. Chayaamor-Heil N, Vitalis L (2020) Biology and architecture: an ongoing hybridization of scientific knowledge and design practice by six architectural offices in France. Front Archit Res. 10(2):240-262. https://doi.org/10.1016/j.foar.2020.10.002

108. Abbati M (2019) CS 11: Case study 11: communicating the environment through the architectural linguistic code. In: Abbati M (ed) Communicating the environment to save the planet: a journey into eco-communication. Springer International Publishing, Cham, pp 431-434

109. Catalano C, Laudicina VA, Badalucco L, Guarino R (2018) Some European green roof norms and guidelines through the lens of biodiversity: do ecoregions and plant traits also matter? Ecol Eng 115: 15-26. https://doi.org/10.1016/j.ecoleng.2018.01.006

110. Salinitro M, Alessandrini A, Zappi A et al (2018) Floristic diversity in different urban ecological niches of a southern European city. Sci Rep 8:15110. https://doi.org/10.1038/s41598-018-33346-6

111. van Stiphout M (2019) First guide to nature inclusive design. Nextcity, p 166

112. Moxon S (2019) Drawing on nature: a vision of an urban residential street adapted for biodiversity in architectural drawings. City Territ Archit 6:6. https://doi.org/10.1186/s40410-019-0105-0

113. Albino V, Berardi U, Dangelico RM (2015) Smart cities: definitions, dimensions, performance, and initiatives. J Urban Technol 22:3-21. https://doi.org/10.1080/10630732.2014.942092

114. Toli AM, Murtagh N (2020) The concept of sustainability in smart city definitions. Front Built Environ 6: 77. https://doi.org/10.3389/fbuil.2020.00077

115. Hassan AM, Lee H (2015) The paradox of the sustainable city: definitions and examples. Environ Dev Sustain 17:1267-1285. https://doi.org/10.1007/s10668-014-9604-z

116. Martin CJ, Evans J, Karvonen A (2018) Smart and sustainable? Five tensions in the visions and practices of the smart-sustainable city in Europe and North America. Technol Forecast Soc Change 133:269-278. https://doi.org/10.1016/j.techfore.2018.01.005

117. Ahvenniemi H, Huovila A, Pinto-Seppä I, Airaksinen M (2017) What are the differences between sustainable and smart cities? Cities 60:234-245. https://doi.org/10.1016/j.cities.2016.09.009

118. Egger S (2006) Determining a sustainable city model. Environ Model Softw 21:1235-1246. https://doi. org/10.1016/j.envsoft.2005.04.012

119. Bibri SE, Krogstie J (2017) Smart sustainable cities of the future: an extensive interdisciplinary literature review. Sustain Cities Soc 31:183-212. https://doi.org/10.1016/j.scs.2017.02.016 
120. Höjer M, Wangel J (2015) Smart sustainable cities: definition and challenges. In: Hilty LM, Aebischer B (eds) ICT innovations for sustainability. Springer International Publishing, Cham, pp 333-349

121. Kutty AA, Abdella GM, Kucukvar M et al (2020) A system thinking approach for harmonizing smart and sustainable city initiatives with United Nations sustainable development goals. Sustain Dev 28:1347-1365. https://doi.org/10.1002/sd.2088

122. Giffinger R, Gudrun H (2010) Smart cities ranking: an effective instrument for the positioning of the cities? ACE Archit City Environ 4:7-26. https://doi.org/10.5821/ace.v4i12.2483

123. López Chao A, Casares Gallego A, Lopez-Chao V, Alvarellos A (2020) Indicators framework for sustainable urban design. Atmosphere 11:1143. https://doi.org/10.3390/atmos11111143

124. Lombardi P, Giordano S, Farouh H, Yousef W (2012) Modelling the smart city performance. Innov Eur J Soc Sci Res 25:137-149. https://doi.org/10.1080/13511610.2012.660325

125. Berardi U (2015) Sustainability assessments of buildings, communities, and cities. In: Klemeš JJ (ed) Assessing and measuring environmental impact and sustainability. Butterworth-Heinemann, Oxford, pp 497-545

126. Murakami S, Kawakubo S, Asami Y et al (2011) Development of a comprehensive city assessment tool: CASBEE-City. Build Res Inf 39:195-210. https://doi.org/10.1080/09613218.2011.563920

127. IBEC (2015) CASBEE for cities. Pilot version for worldwide use (2015). Institute for Building Environment and Energy Conservation (IBEC), Tokyo

128. Kawakubo S, Murakami S, Ikaga T, Asami Y (2018) Sustainability assessment of cities: SDGs and GHG emissions. Build Res Inf 46:528-539. https://doi.org/10.1080/09613218.2017.1356120

129. Miyazaki G, Kawakubo S, Murakami S, Ikaga T (2019) How can CASBEE contribute as a sustainability assessment tool to achieve the SDGs? IOP Conf Ser Earth Environ Sci 294:012007. https://doi.org/10. 1088/1755-1315/294/1/012007

130. Chan L, Elmqvist T, Holman N et al (2014) User's manual on the Singapore index on cities' biodiversity (also known as the City Biodiversity Index). National Parks Board, Singapore

131. Chan L, Djoghlaf A (2009) Invitation to help compile an index of biodiversity in cities. Nature 460:33-33. https://doi.org/10.1038/460033a

132. Uchiyama Y, Kohsaka R (2020) Indicators and practices of urban biodiversity and sustainability. In: Leal Filho W, Marisa Azul A, Brandli L, et al (eds) Sustainable cities and communities. Springer International Publishing, Cham, pp 300-308

133. Uchiyama Y, Hayashi K, Kohsaka R (2015) Typology of cities based on City Biodiversity Index: exploring biodiversity potentials and possible collaborations among Japanese cities. Sustainability 7: 14371-14384. https://doi.org/10.3390/su71014371

134. Uchiyama Y, Kohsaka R (2017) Spatio-temporal analysis of biodiversity, land-use mix and human population in a socio-ecological production landscape: a case study in the Hokuriku Region, Japan. Procedia Eng 198:219-226. https://doi.org/10.1016/j.proeng.2017.07.086

135. Tateishi R, Hoan NT, Kobayashi T et al (2014) Production of global land cover data - GLCNMO2008. https://doi.org/10.5539/JGG.V6N3P99

136. Deslauriers MR, Asgary A, Nazarnia N, Jaeger JAG (2018) Implementing the connectivity of natural areas in cities as an indicator in the City Biodiversity Index (CBI). Ecol Indic 94:99-113. https://doi.org/10. 1016/j.ecolind.2017.02.028

137. DGNB (2020) DGNB System. New construction, buildings criteria set. Deutsche Gesellschaft für Nachhaltiges Bauen (German Sustainable Building Council) - DGNB e.V., Stuttgart

138. DGNB (2020) Bauen für eine bessere Welt. Wie Gebäude einen Beitrag zu den globalen Nachhaltigkeitszielen der Vereinten Nationen leisten. Deutsche Gesellschaft für Nachhaltiges Bauen DGNB e.V, Stuttgart

139. Renger BC, Birkeland JL, Midmore DJ (2015) Net-positive building carbon sequestration. Build Res Inf 43:11-24. https://doi.org/10.1080/09613218.2015.961001

140. Franklin J (2010) Mapping species distributions: spatial inference and prediction. Cambridge University Press

141. Phillips SJ, Anderson RP, Schapire RE (2006) Maximum entropy modeling of species geographic distributions. Ecol Model 190:231-259. https://doi.org/10.1016/j.ecolmodel.2005.03.026

142. Gevrey M, Worner S, Kasabov N et al (2006) Estimating risk of events using SOM models: a case study on invasive species establishment. Ecol Model 197:361-372. https://doi.org/10.1016/j.ecolmodel.2006.03. 032

143. Heikkinen RK, Pöyry J, Virkkala R et al (2015) Modelling potential success of conservation translocations of a specialist grassland butterfly. Biol Conserv 192:200-206. https://doi.org/10.1016/j.biocon.2015.09. 028 
144. Thuiller W (2003) BIOMOD - optimizing predictions of species distributions and projecting potential future shifts under global change. Glob Chang Biol 9:1353-1362. https://doi.org/10.1046/j.1365-2486. 2003.00666.x

145. Pe'er G, Matsinos YG, Johst K et al (2013) A protocol for better design, application, and communication of population viability analyses. Conserv Biol 27:644-656. https://doi.org/10.1111/cobi.12076

146. Bocedi G, Palmer SCF, Pe'er G et al (2014) RangeShifter: a platform for modelling spatial ecoevolutionary dynamics and species' responses to environmental changes. Methods Ecol Evol 5:388396. https://doi.org/10.1111/2041-210x.12162

147. Pe'er G, Henle K, Dislich C, Frank K (2011) Breaking functional connectivity into components: a novel approach using an individual-based model, and first outcomes. PLoS One 6:e22355. https://doi.org/10. 1371/journal.pone.0022355

148. Grimm V, Lorek H, Finke J et al (2004) META-X: generic software for metapopulation viability analysis. Biodivers Conserv 13:165-188. https://doi.org/10.1023/B:BIOC.0000004317.42949.f7

149. Moulherat S, Le Roux D, de Roincé C et al (2019) Biodiversité. BIM et Infrastructures 52

150. Carvalho JP, Bragança L, Mateus R (2020) A Systematic review of the role of BIM in building sustainability assessment methods. Appl Sci 10:4444. https://doi.org/10.3390/app10134444

151. Flaxman M (2009) Fundamentals of Geodesign. Peer Reviewed Proceedings of Digital Landscape Architecture 2010 at Anhalt University of Applied Sciences.

152. Jupp J (2017) 4D BIM for environmental planning and management. Procedia Eng 180:190-201. https:// doi.org/10.1016/j.proeng.2017.04.178

153. Flaxman M (2009) Fundamentals of Geodesign

154. Mignard C, Nicolle C (2014) Merging BIM and GIS using ontologies application to urban facility management in ACTIVe3D. Comput Ind 65:1276-1290. https://doi.org/10.1016/j.compind.2014.07.008

155. Fountain J, Langar S (2018) Building information modeling (BIM) outsourcing among general contractors. Autom Constr 95:107-117. https://doi.org/10.1016/j.autcon.2018.06.009

156. Lu Y, Wu Z, Chang R, Li Y (2017) Building information modeling (BIM) for green buildings: a critical review and future directions. Autom Constr 83:134-148. https://doi.org/10.1016/j.autcon.2017.08.024

157. Steinitz C (2016) Beginnings of GeoDesign: a personal historical perspective. Res Urban Ser 4:9-24. https://doi.org/10.7480/rius.4.1366

158. Ervin S (2012) A system for GeoDesign. Proceedings of Digital Landscape Architecture 2011:145-154

159. ANZLIC (2019) Principles for spatially enabled digital twins of the built and natural environment in Australia. The Australia and New Zealand Land Information Council (ANZLIC), pp 22

160. Grieves M (2016) Origins of the digital twin concept. https://doi.org/10.13140/RG.2.2.26367.61609

161. Daskalova M (2018) The 'digital twin' - a bridge between the physical and the digital world. In: Cobuilder. https://cobuilder.com/en/the-digital-twin-a-bridge-between-the-physical-and-the-digital-world/. Accessed 26 Jan 2021

162. Meslec M, Steger B, Druhmann CK (2019) Common data environment for sustainable smart real estate portfolios. International Council for Research and Innovation in Building and Construction, pp 1858-1868

163. de Laat R, van Berlo L (2011) Integration of BIM and GIS: the development of the CityGML GeoBIM extension. In: Kolbe TH, König G, Nagel C (eds) Advances in 3D geo-information sciences. Springer, Berlin, Heidelberg, pp 211-225

164. Caetano I, Santos L, Leitão A (2020) Computational design in architecture: defining parametric, generative, and algorithmic design. Front Archit Res 9:287-300. https://doi.org/10.1016/j.foar.2019.12.008

165. Frazer J, Frazer J, Xiyu L et al (2002) Generative and evolutionary techniques for building envelope design. Milan, Italy, p 18

166. Çalışkan O (2017) Parametric Design in urbanism: a critical reflection. Plan Pract Res 32:417-443. https:// doi.org/10.1080/02697459.2017.1378862

167. Price J (1999) Christopher Alexander's pattern language. IEEE Trans Prof Commun 42:117-122. https:// doi.org/10.1109/47.804820

168. Alexander C (1977) A pattern language: towns, buildings, construction. Oxford University Press

169. Feng K, Lu W, Wang Y (2019) Assessing environmental performance in early building design stage: An integrated parametric design and machine learning method. Sustain Cities Soc 50:101596. https://doi.org/ 10.1016/j.scs.2019.101596

170. Marsault X (2017) Eco-design. In: Eco-generative design for early stages of architecture. John Wiley \& Sons, Ltd, pp 21-48

171. Marsault X, Torres F (2019) An interactive and generative eco-design tool for architects in the sketch phase. J Phys Conf Ser 1343:012136. https://doi.org/10.1088/1742-6596/1343/1/012136

172. Jusselme T, Cozza S, Hoxha E, et al (2016) Towards a pre-design method for low carbon architectural strategies. In: Proceedings of PLEA 2016, 32th international Conference on Passive and Low Energy Architecture 
173. Abrishami S, Goulding J, Rahimian FP, Ganah A (2014) Integration of BIM and generative design to exploit AEC conceptual design innovation. Inf Technol Constr 19:350-359

174. Dautremont C, Jancart S, Dagnelie C, Stals A (2019) Parametric design and BIM, systemic tools for circular architecture. IOP Conf Ser Earth Environ Sci 225:012071. https://doi.org/10.1088/1755-1315/225/ $1 / 012071$

175. Jusselme T, Rey E, Andersen M (2018) An integrative approach for embodied energy: towards an LCAbased data-driven design method. Renew Sust Energ Rev 88:123-132. https://doi.org/10.1016/j.rser.2018. 02.036

176. Jusselme T, Antunes Fernandes P, Rey E, Andersen M (2019) Design guidance from a data-driven LCAbased design method and tool prototype. In: Proceedings of Building Simulation 2019: 16th Conference of IBPSA

177. Nault É, Aguacil Moreno S, Jusselme T (2020) Analysis and visualisation of decision paths towards reaching environmental impact targets at early-design stage. In: Proceedings of 35 th Passive and Low Energy Architecture PLEA 2020 Conference, 1st-3rd September 2020, Coruña, Spain. 1-3 September 2020

178. Jusselme T (2020) Data-driven method for low-carbon building design at early stages. PhD Thesis, EPFL

179. Nault E, Jusselme T, Aguacil S, Andersen M (2020) Strategic environmental urban planning - a contextual approach for defining performance goals and informing decision-making. Build Environ 168:106448. https://doi.org/10.1016/j.buildenv.2019.106448

180. Marin P, Marsault X, Saleri R, Duchanois G (2012) Creativity with the help of evolutionary design tool. In: Achten H, Pavliček J, Hulín J, Matějovská D (eds) Digital Physicality, 1st ed. eCAADe (Education and research in Computer Aided Architectural Design in Europe) and ČVUT, Faculty of Architecture, Prague, pp 319-327

181. Marsault X (2017) The EcoGen software program. In: Eco-generative design for early stages of architecture. John Wiley \& Sons, Ltd, pp 105-141

182. Hensel MU, Killi S, Sørensen S (2017) Performance-oriented design — an integrative approach to datadriven design including associative computational modeling, computational analysis, advanced computational visualization and rapid prototyping. Proceeding of The International Conference on Sustainable Smart Manufacturing S2M

183. Hensel MU, Sørensen SS (2019) Performance-oriented architecture and urban design: relating information-based design and systems-thinking in architecture. FORMakademisk 12:1-17. https://oi. org/10.7577/formakademisk.2963

184. Janssen P, Stouffs R (2015) Types of parametric modelling. In: Emerging experience in past, present and future of digital architecture, Proceedings of the 20th International Conference of the Association for Computer-Aided Architectural Design Research in Asia (CAADRIA 2015) / Daegu. CUMINCAD, pp 157-166

185. Yanarella E, Levine R (2011) Charter of European Cities an Towards Sustainability. In the City as Fulcrum of Global Sustainability Anthem Press. https://doi.org/10.7135/UPO9780857284006.016

186. The Aalborg Charter (1994) Charter of europeans cities and towns towards sustainability

187. Friedman Y (1978) L'Architecture de survie: où s'invente aujourd'hui le monde de demain. Editions Casterman, Tournai-Paris, France

188. Carpenter S, Walker B, Anderies JM, Abel N (2001) From metaphor to measurement: resilience of what to what? Ecosystems 4:765-781. https://doi.org/10.1007/s10021-001-0045-9

189. Gunderson LH (2000) Ecological resilience - in theory and application. Annu Rev Ecol Syst 31:425-439. https://doi.org/10.1146/annurev.ecolsys.31.1.425

190. Holling CS (1973) Resilience and stability of ecological systems. Annu Rev Ecol Syst 4:1-23. https://doi. org/10.1146/annurev.es.04.110173.000245

191. Meyer K (2016) A mathematical review of resilience in ecology. Nat Resour Model 29:339-352. https:// doi.org/10.1111/nrm.12097

192. Gunderson LH, Pritchard L (2002) Resilience and the behavior of large scale systems. Island Press, Washington, D.C

193. Bjögvinsson E, Ehn P, Hillgren P-A (2012) Design things and design thinking: contemporary participatory design challenges. Des Issues 28:101-116. https://doi.org/10.1162/DESI_a_00165

194. Sevaldson B (2018) Visualizing complex design: the evolution of gigamaps. In: Jones P, Kijima K (eds) Systemic design: theory, methods, and practice. Springer Japan, Tokyo, pp 243-269

195. UN-HABITAT (2020) World cities report 2020: the value of sustainable urbanization. United Nations.

196. Rosin ZM, Hiron M, Żmihorski M et al (2020) Reduced biodiversity in modernized villages: a conflict between sustainable development goals. J Appl Ecol 57:467-475. https://doi.org/10.1111/1365-2664. 13566 
197. Albert CH, Rayfield B, Dumitru M, Gonzalez A (2017) Applying network theory to prioritize multispecies habitat networks that are robust to climate and land-use change: prioritizing a network for biodiversity. Conserv Biol 31:1383-1396. https://doi.org/10.1111/cobi.12943

198. Baguette M, Blanchet S, Legrand D et al (2013) Individual dispersal, landscape connectivity and ecological networks. Biol Rev 88:310-326. https://doi.org/10.1111/brv.12000

199. Matos C, Petrovan SO, Wheeler PM, Ward AI (2019) Landscape connectivity and spatial prioritization in an urbanising world: a network analysis approach for a threatened amphibian. Biol Conserv 237:238-247. https://doi.org/10.1016/j.biocon.2019.06.035

200. Urban D, Keitt T (2001) Landscape connectivity: a graph-theoretic perspective. Ecology 82:1205-1218. https://doi.org/10.1890/0012-9658(2001)082[1205:lcagtp]2.0.co;2

201. Hostetler M, Allen W, Meurk C (2011) Conserving urban biodiversity? Creating green infrastructure is only the first step. Landsc Urban Plan 100:369-371. https://doi.org/10.1016/j.landurbplan.2011.01.011

202. Robinson J, Mills J, Breed M (2018) Walking ecosystems in microbiome-inspired green infrastructure: an ecological perspective on enhancing personal and planetary health. Challenges 9:40. https://doi.org/10. 3390/challe9020040

203. Mohamed ASY, Moumani K (2019) Bioclimatism through Vernacular architecture as a pass for new sustainable structure. Acad Res Community Publ 3:50-70. https://doi.org/10.21625/archive.v3i3.522

204. Capotorti G, Bonacquisti S, Abis L, Aloisi I, Attorre F, Bacaro G, Balletto G, Banfi E, Barni E, Bartoli F, Bazzato E, Beccaccioli M, Braglia R, Bretzel F, Brighetti MA, Brundu G, Burnelli M, Calfapietra C, Cambria VE, Caneva G, Canini A, Caronni S, Castello M, Catalano C, Celesti-Grapow L, Cicinelli E, Cipriani L, Citterio S, Concu G, Coppi A, Corona E, del Duca S, del VE, di Gristina E, Domina G, Faino L, Fano EA, Fares S, Farris E, Farris S, Fornaciari M, Gaglio M, Galasso G, Galletti M, Gargano ML, Gentili R, Giannotta AP, Guarino C, Guarino R, Iaquinta G, Iiriti G, Lallai A, Lallai E, Lattanzi E, Manca S, Manes F, Marignani M, Marinangeli F, Mariotti M, Mascia F, Mazzola P, Meloni G, Michelozzi P, Miraglia A, Montagnani C, Mundula L, Muresan AN, Musanti F, Nardini A, Nicosia E, Oddi L, Orlandi F, Pace R, Palumbo ME, Palumbo S, Parrotta L, Pasta S, Perini K, Poldini L, Postiglione A, Prigioniero A, Proietti C, Raimondo FM, Ranfa A, Redi EL, Reverberi M, Roccotiello E, Ruga L, Savo V, Scarano P, Schirru F, Sciarrillo R, Scuderi F, Sebastiani A, Siniscalco C, Sordo A, Suanno C, Tartaglia M, Tilia A, Toffolo C, Toselli E, Travaglini A, Ventura F, Venturella G, Vincenzi F, Blasi C (2020) More nature in the city. Plant Biosyst - Int J Deal Asp Plant Biol 154:1-4. https://doi.org/10.1080/11263504.2020.1837285

205. Baker DJ, Maclean IMD, Goodall M, Gaston KJ (2021) Species distribution modelling is needed to support ecological impact assessments. J Appl Ecol 58:21-26. https://doi.org/10.1111/1365-2664.13782

206. Simmonds JS, Sonter LJ, Watson JEM et al (2020) Moving from biodiversity offsets to a target-based approach for ecological compensation. Conserv Lett 13:e12695. https://doi.org/10.1111/conl.12695

207. Moilanen A, Kotiaho JS (2018) Fifteen operationally important decisions in the planning of biodiversity offsets. Biol Conserv 227:112-120. https://doi.org/10.1016/j.biocon.2018.09.002

208. Noss RF (1990) Indicators for monitoring biodiversity: a hierarchical approach. Conserv Biol 4:355-364. https://doi.org/10.1111/j.1523-1739.1990.tb00309.x

209. Fagan WF, Holmes EE (2006) Quantifying the extinction vortex. Ecol Lett 9:51-60. https://doi.org/10. 1111/j.1461-0248.2005.00845.x

210. Hanski I (1998) Metapopulation dynamics. Nature 396:41-49. https://doi.org/10.1016/0169-5347(89) 90061-X

211. Hanski I (1999) Habitat connectivity, habitat continuity, and metapopulations in dynamic landscapes. Oikos 87:209-219. https://doi.org/10.2307/3546736

212. Hanski I, Moilanen A, Gyllenberg M (1996) Minimum viable metapopulation size. Am Nat 147:527-541. https://doi.org/10.1086/285864

213. Turlure C, Schtickzelle N, Dubois Q et al (2019) Suitability and transferability of the resource-based habitat concept: a test with an assemblage of butterflies. Front Ecol Evol 7:127. https://doi.org/10.3389/ fevo.2019.00127

214. Berryman AA, Hawkins BA, Hawkins BA (2006) The refuge as an integrating concept in ecology and evolution. Oikos 115:192-196. https://doi.org/10.1111/j.0030-1299.2006.15188.x

215. Ducatez S, Sayol F, Sol D, Lefebvre L (2018) Are urban vertebrates city specialists, artificial habitat exploiters, or environmental generalists? Integr Comp Biol. 58(5):929-938. https://doi.org/10.1093/icb/icy101

216. Hamer AJ, McDonnell MJ (2008) Amphibian ecology and conservation in the urbanising world: a review. Biol Conserv 141:2432-2449. https://doi.org/10.1016/j.biocon.2008.07.020

217. Herr J, Schley L, Roper TJ (2009) Socio-spatial organization of urban stone martens. J Zool 277:54-62. https://doi.org/10.1111/j.1469-7998.2008.00510.x

218. Penone C, Machon N, Julliard R, Le Viol I (2012) Do railway edges provide functional connectivity for plant communities in an urban context? Biol Conserv 148:126-133. https://doi.org/10.1016/j.biocon.2012. 01.041 
219. Barazzetti L, Banfi F (2017) BIM and GIS: when parametric modeling meets geospatial data. ISPRS Ann Photogramm Remote Sens Spat Inf Sci IV-5(W1):1-8. https://doi.org/10.5194/isprs-annals-IV-5-W1-12017

220. Noardo F, Wu T, Arroyo Ohori K et al (2020) GeoBIM for digital building permit process: learning from a case study in Rotterdam. In: ISPRS Annals of Photogrammetry. Remote Sensing and Spatial Information Sciences, Copernicus GmbH, pp 151-158

221. Wortmann T, Tunçer B (2017) Differentiating parametric design: digital workflows in contemporary architecture and construction. Des Stud 52:173-197. https://doi.org/10.1016/j.destud.2017.05.004

222. Hanan J, Prusinkiewicz P, Zalucki M, Skirvin D (2002) Simulation of insect movement with respect to plant architecture and morphogenesis. Comput Electron Agric 35:255-269. https://doi.org/10.1016/S01681699(02)00022-4

223. Goddard MA, Dougill AJ, Benton TG (2010) Scaling up from gardens: biodiversity conservation in urban environments. Trends Ecol Evol 25:90-98. https://doi.org/10.1016/j.tree.2009.07.016

224. Kueffer C, Di Giulio M, Hauser K, Wiedmer C (2020) Time for a biodiversity turn in sustainability science. GAIA - Ecol Perspect Sci Soc 29:272-274. https://doi.org/10.14512/gaia.29.4.14

225. Capra F (2007) Sustainable living, ecological literacy, and the breath of life. Can J Environ Educ 12:9-18

226. McBride BB, Brewer CA, Berkowitz AR, Borrie WT (2013) Environmental literacy, ecological literacy, ecoliteracy: what do we mean and how did we get here? Ecosphere 4:art67. https://doi.org/10.1890/ES1300075.1

227. Johnson BR, Hill K (2002) Ecology and design: frameworks for learning. Island Press, Washington, D.C.

228. Flaxman M (2009) Fundamentals of Geodesign. Peer Reviewed Proceedings of Digital Landscape Architecture 2010 at Anhalt University of Applied Sciences

229. Yanarella E, Levine R (2011) Charter of European Cities and towns towards sustainability. In: The City as Fulcrum of Global Sustainability. Anthem Press, pp 237-244. https://doi.org/10.7135/ UPO9780857284006.016

\section{Affiliations}

Chiara Catalano $^{1} \cdot$ Mihaela Meslec $^{1} \cdot$ Jules Boileau $^{2,3} \cdot$ Riccardo Guarino $^{4} \cdot$ Isabella Aurich $^{1} \cdot$ Nathalie Baumann $^{1}$ • Frédéric Chartier ${ }^{5}$ - Pascale Dalix ${ }^{5} \cdot$ Sophie Deramond $^{5}$. Patrick Laube $^{1}$ - Angela Ka Ki Lee ${ }^{5}$ - Pascal Ochsner ${ }^{1}$ - Marine Pasturel ${ }^{2}$ - Marie Soret $^{2,6} \cdot$ Sylvain Moulherat ${ }^{2,7}$

1 Department Life Sciences and Facility Management, Zurich University of Applied Science, Institute for Natural Resource Sciences, Grüentalstrasse 14, 8820 Wädenswil, Switzerland

2 TerrOiko-OikoLab, 14 rue Ferlus, BP 26, 31250 Revel, France

3 Centre d'Ecologie Fonctionnelle et Evolutive (UMR 5175), 1919 route de Mende, 34293 Montpellier 5, France

4 Department of Biological, Chemical and Pharmaceutical Sciences and Technologies (STEBICEF)-Botanical Unit, University of Palermo, Palermo, Italy

5 Chartier Dalix Architects, 27 Rue Popincourt, 75011 Paris, France

6 Territoire Environement, Télédétection et Information Spatiale (UMR 9000), INRAE, Maison de la Télédétection, 500 rue Jean-François Breton, 34000 Montpellier, France

7 Station d'Ecologie Théorique et Expérimentale (UMR 5321), 2 Route du CNRS, 09200 Moulis, France 